\title{
Distinct patterns in the diurnal and seasonal variability in four components of soil respiration in a temperate forest under free-air $\mathrm{CO}_{2}$ enrichment
}

\author{
L. Taneva and M. A. Gonzalez-Meler \\ Ecology and Evolution Group, Department of Biological Sciences, University of Illinois at Chicago, \\ 845 W. Taylor Street M/C 066, Chicago IL 60607, USA \\ Received: 1 March 2011 - Published in Biogeosciences Discuss.: 18 March 2011 \\ Revised: 10 October 2011 - Accepted: 21 October 2011 - Published: 31 October 2011
}

\begin{abstract}
Soil respiration $\left(R_{\mathrm{S}}\right)$ is a major flux in the global carbon (C) cycle. Responses of $R_{\mathrm{S}}$ to changing environmental conditions may exert a strong control on the residence time of $\mathrm{C}$ in terrestrial ecosystems and in turn influence the atmospheric concentration of greenhouse gases. Soil respiration consists of several components oxidizing soil $\mathrm{C}$ from different pools, age and chemistry. The mechanisms underlying the temporal variability of $R_{\mathrm{S}}$ components are poorly understood. In this study, we used the long-term wholeecosystem ${ }^{13} \mathrm{C}$ tracer at the Duke Forest Free Air $\mathrm{CO}_{2} \mathrm{En}$ richment site to separate forest $R_{\mathrm{S}}$ into its autotrophic $\left(R_{\mathrm{R}}\right)$ and heterotrophic components $\left(R_{\mathrm{H}}\right)$. The contribution of $R_{\mathrm{H}}$ to $R_{\mathrm{S}}$ was further partitioned into litter decomposition $\left(R_{\mathrm{L}}\right)$, and decomposition of soil organic matter $\left(R_{\mathrm{SOM}}\right)$ of two age classes - up to $8 \mathrm{yr}$ old and SOM older than $8 \mathrm{yr}$. Soil respiration was generally dominated by $R_{\mathrm{SOM}}$ during the growing season (44\% of daytime $R_{\mathrm{S}}$ ), especially at night. The contribution of heterotrophic respiration $\left(R_{\mathrm{SOM}}\right.$ and $\left.R_{\mathrm{L}}\right)$ to $R_{\mathrm{S}}$ was not constant, indicating that the seasonal variability in $R_{\mathrm{R}}$ alone cannot explain seasonal variation in $R_{\mathrm{S}}$. Although there was no diurnal variability in $R_{\mathrm{S}}$, there were significant compensatory differences in the contribution of individual $R_{\mathrm{S}}$ components to daytime and nighttime rates. The average contribution of $R_{\mathrm{SOM}}$ to $R_{\mathrm{S}}$ was greater at night (54\%) than during the day (44\%). The average contribution of $R_{\mathrm{R}}$ to total $R_{\mathrm{S}}$ was $\sim 30 \%$ during the day and $\sim 34 \%$ during the night. In contrast, $R_{\mathrm{L}}$ constituted $26 \%$ of $R_{\mathrm{S}}$ during the day and only $12 \%$ at night. About $95 \%$ of the decomposition of soil C older than $8 \mathrm{yr}\left(R_{\text {pre-tr }}\right)$ originated from $R_{\mathrm{SOM}}$ and
\end{abstract}

\section{Correspondence to: \\ M. A. Gonzalez-Meler}

(mmeler@uic.edu) showed more pronounced and consistent diurnal variability than any other $R_{\mathrm{S}}$ component; nighttime rates were on average $29 \%$ higher than daytime rates. In contrast, the decomposition of more recent, post-treatment $\mathrm{C}\left(R_{\text {pre-tr }}\right)$ did not vary diurnally. None of the diurnal variations in components of $R_{\mathrm{H}}$ could be explained by only temperature and moisture variations. Our results indicate that the variation observed in the components of $R_{\mathrm{S}}$ is the result of complex interaction between dominant biotic controls (e.g. plant activity, mineralization kinetics, competition for substrates) over abiotic controls (temperature, moisture). The interactions and controls among roots and other soil organisms that utilize $\mathrm{C}$ of different chemistry, accessibility and ages, results in the overall soil $\mathrm{CO}_{2}$ efflux. Therefore understanding the controls on the components of $R_{\mathrm{S}}$ is necessary to elucidate the influence of ecosystem respiration on atmospheric C-pools at different time scales.

\section{Introduction}

Terrestrial ecosystems exchange large amounts of $\mathrm{C}$ with the atmosphere through the processes of photosynthesis and ecosystem respiration $\left(R_{\mathrm{E}}\right)$. Annually, the difference between these large fluxes determines the extent of $\mathrm{C}$ storage in the terrestrial biosphere and small imbalances between these fluxes can lead to substantial variation in atmospheric $\mathrm{CO}_{2}$ concentration. The role of ecosystems as a long-term sink or source for atmospheric $\mathrm{C}$ thus depends on the effects and feedbacks of changing environmental conditions on photosynthesis and the components of $R_{\mathrm{E}}$. The potential responses of $R_{\mathrm{E}}$ to environmental change are less clear than those of photosynthesis (Gonzalez-Meler et al., 2004; DeLucia et al.,

Published by Copernicus Publications on behalf of the European Geosciences Union. 
2007), but are of fundamental importance in determining the residence time of $\mathrm{C}$ in terrestrial ecosystems. Improved understanding of the biotic and abiotic mechanisms controlling $\mathrm{C}$ release from terrestrial ecosystems, and the time scales at which these mechanisms operate, is necessary before the future role of the terrestrial biosphere in the global $\mathrm{C}$ cycle can be predicted.

Ecosystem respiration is often dominated by soil respiration $\left(R_{\mathrm{S}}\right)$, which can constitute $50-80 \%$ of the total C emitted from ecosystems to the atmosphere annually (Raich et al., 2002; Davidson and Janssens, 2006; Davidson et al., 2006). Soil respiration results from a complex network of oxidation processes, involving different substrates of various ages and carried out by different organisms at different temporal and spatial scales (Taneva et al., 2006). Soil respiration includes respiration by live roots, root-associated microorganisms, and microbial decomposition of root exudates (collectively referred to as root/rhizosphere respiration, $R_{\mathrm{R}}$ ), as well as from heterotrophic respiration $\left(R_{\mathrm{H}}\right)$ associated with the decomposition of root and leaf litter, and other soil organic matter (SOM) pools of different ages. Ecosystem exposure to elevated $\left[\mathrm{CO}_{2}\right]$ or high temperature has been shown to lead to enhanced $R_{\mathrm{S}}$ rates only initially (King et al., 2004; Bernhardt et al., 2006; Melillo et al., 2002). It remains unclear whether changes in $R_{\mathrm{S}}$ of ecosystems exposed to elevated $\mathrm{CO}_{2}$ or warming are the result of increased $R_{\mathrm{R}}, R_{\mathrm{H}}$, or a combination of both (Gonzalez-Meler and Taneva, 2005; Subke et al., 2006; Bradford et al., 2008).

Because individual components of $R_{\mathrm{S}}$ return soil carbon of different nature and age back to the atmosphere, a shift in their relative contributions to total $R_{\mathrm{S}}$ with environmental changes, will impact the residence time of soil $\mathrm{C}$ and, therefore, atmospheric $\mathrm{CO}_{2}$ concentration levels. For instance, atmospheric $\mathrm{CO}_{2}$ enrichment may cause increases in belowground allocation (Matamala and Schlesinger, 2000; Norby et al., 2002) leading to increased total $R_{\mathrm{R}}$ rates. Increases in $R_{\mathrm{S}}$ rates caused solely by a photosynthesis-driven direct enhancement of $R_{\mathrm{R}}$ may have little consequence to SOM pool changes and atmospheric $\mathrm{CO}_{2}$ concentration. Greater soil $\mathrm{C}$ inputs under elevated $\left[\mathrm{CO}_{2}\right]$ may also increase substrate availability to soil microorganisms and lead to higher $R_{\mathrm{H}}$ rates (Hamilton et al., 2002; Makiranta et al., 2008; Wei et al., 2010). Heterotrophic respiration returns older soil C to the atmosphere and changes in both the sources and rates of $R_{\mathrm{H}}$ with environmental conditions (e.g. elevated $\left[\mathrm{CO}_{2}\right]$, plant activity, altered soil moisture and/or temperature) could substantially affect the $\mathrm{C}$ sink capacity and turnover of soil C, with the potential to affect atmospheric $\left[\mathrm{CO}_{2}\right]$.

Partitioning $R_{\mathrm{S}}$ into its components is inherently difficult and a variety of methods have been applied to the separation of $R_{\mathrm{R}}$ from $R_{\mathrm{H}}$ (Hanson et al., 2000; Subke et al., 2006). The average contribution of $R_{\mathrm{R}}$ to total $R_{\mathrm{S}}$ in temperate forests has been estimated to be $\sim 45 \%$, with a range of 10 to $90 \%$ (Hanson et al., 2000; Bond-Lamberty et al., 2004). The proportion of $R_{\mathrm{R}}$ has been shown to be related to annual
$R_{\mathrm{S}}$ rates and may not be constant across temporal or spatial scales (Bond-Lamberty et al., 2004; Subke et al., 2006; Kuzyakov and Gavrichkova, 2010), challenging the use of a single annual value for $R_{\mathrm{R}} / R_{\mathrm{S}}$ in terrestrial $\mathrm{C}$ cycle models. An emerging pattern from $R_{\mathrm{E}}$ partitioning studies is that photosynthesis exerts a strong influence on $R_{\mathrm{S}}$ on diel and seasonal time scales (Högberg et al., 2001; Bowling et al., 2002; Tang et al., 2005; Kuzyakov and Gavrichkova, 2010). Trueman and Gonzalez-Meler (2005) showed that the rates of oxidation of soil pools that contained $\mathrm{C}$ older than $4 \mathrm{yr}$ were highly influenced by changes in plant activity. These observations suggest that there are complex interactive effects between $R_{\mathrm{S}}$ components that may operate at different time scales, involving several soil $\mathrm{C}$ pools that may differ in chemical composition and soil residence time (Heath et al., 2005). The interactive effects of biotic and abiotic variables on $R_{\mathrm{S}}$ and its components have not been elucidated.

Temperature- and moisture-dependent models are widely used for predicting the response of terrestrial ecosystems to changing environmental conditions (Lloyd and Taylor, 1994; Reichstein et al., 2003; Luo, 2007). Individual components of $R_{\mathrm{S}}$, however, can often be independently affected by other abiotic or biotic variables, as well as by their interactions (Trueman and Gonzalez-Meler, 2005; Kuzyakov and Gavrichkova, 2010). A significant amount of photosynthetic carbon is returned to the atmosphere through $R_{\mathrm{R}}$ within days of assimilation (Ekblad and Hogberg, 2001; Bowling et al., 2002; Trueman and Gonzalez-Meler, 2005; Taneva et al., 2006; Carbone et al., 2007; Mencuccini and Hölttä, 2010; Kuzyakov and Gravrichkova, 2010), highlighting the importance of photosynthesis in influencing $R_{\mathrm{S}}$ rates. Enhanced plant activity may also lead to changes in the decomposition rate of older SOM through "priming", if they result in changes in the size of the SOM pool (Kuzyakov, 2002; Subke et al., 2004). Biotic controls on the rate of the components of $R_{\mathrm{S}}$ can also be confounded with the temperature- and moisture-dependent functions often used to describe variations in $R_{\mathrm{S}}$ at seasonal time scales, potentially leading to limitations in our mechanistic predictions of ecosystem $\mathrm{C}$ budgets (Liu et al., 2006).

In this study, we used litter removal and the long-term ${ }^{13} \mathrm{C}$ tracer at the Duke Forest Free Air $\mathrm{CO}_{2}$ Enrichment (FACE) experiment (Chapel Hill, NC, USA) to partition growing season $R_{\mathrm{S}}$ into the contributions of root/rhizosphere respiration, litter decomposition, and decomposition of SOM. We also separated an older than $8 \mathrm{yr} \mathrm{C}$ pool based on the time at which elevated $\mathrm{CO}_{2}$ exposure began (1996). Stable isotope labeling techniques have been used successfully to partition $R_{\mathrm{S}}$ into some of its components (e.g. Andrews et al., 1999; Matamala et al., 2003; Taneva et al., 2006) as isotopes provide a nondisruptive alternative to destructive methods for distinguishing the origin of soil-respired $\mathrm{CO}_{2}$. Our specific objectives were: (1) to determine the diel and seasonal variability of the components of $R_{\mathrm{S}}$; and (2) to understand how variations in $R_{\mathrm{S}}$ components affect observed rates of $R_{\mathrm{S}}$. 


\section{Materials and methods}

\subsection{Site description}

The Forest Atmosphere Carbon Transfer and Storage 1 (FACTS-1) research site is located in the Blackwood Division of the Duke Forest, near Chapel Hill, North Carolina, USA $\left(35^{\circ} 58^{\prime} \mathrm{N} 79^{\circ} 05^{\prime} \mathrm{W}\right)$. The Free Air $\mathrm{CO}_{2}$ Enrichment (FACE) experiment at FACTS-1 consists of six 30-m diameter plots in an intact Pinus taeda plantation. Of the six plots, three are fumigated with $\mathrm{CO}_{2}$ to maintain atmospheric $\left[\mathrm{CO}_{2}\right]$ about $200 \mu \mathrm{l}^{-1}$ above ambient levels $\left(567 \pm 4 \mu \mathrm{l}^{-1}\right.$ 1996-2004; K. Lewin and R. Nettles, personal communication, 2009). The other three control plots are fumigated with ambient air only (Hendrey et al., 1999). Continuous fumigation of all plots began on 27 August 1996, $15 \mathrm{yr}$ after planting. $\mathrm{CO}_{2}$ fumigation is switched off when temperatures are below $5^{\circ} \mathrm{C}$ and when sustained wind speed exceeds $5 \mathrm{~m} \mathrm{~s}^{-1}$ and since 2003 fumigation was limited to daytime only.

Although dominated by pines through natural succession, a number of hardwood species have become established in the understory (Acer rubrum, Liquidambar styraciflua, Liriodendron tulipifera, Ulmus alata, and Cercis Canadensis). Soils at the site are clay-rich, low fertility Ultic Alfisols, with a $\mathrm{pH}$ of about 5. Fine roots are found mostly in the upper $20 \mathrm{~cm}$ of the soil profile (Matamala and Schlesinger, 2000). Mean annual temperature is $15.5^{\circ} \mathrm{C}$ and mean annual precipitation is $1140 \mathrm{~mm}$.

\subsection{Ecosystem ${ }^{13} \mathrm{C}$ tracer}

The $\mathrm{CO}_{2}$ used in FACE experiments is usually depleted in ${ }^{13} \mathrm{C}\left(\left(\delta^{13} \mathrm{C} \approx-43.1 \pm 0.6 \%\right.\right.$ vs. $\mathrm{PDB}$, where $\delta^{13} \mathrm{C}=\left[\left(R_{\text {sample }}-R_{\text {reference }}\right) / R_{\text {reference }}\right] \cdot 1000$ and $R={ }^{13} \mathrm{C} /$ $\left.{ }^{12} \mathrm{C}\right)$. The $\mathrm{CO}_{2}$ released in the elevated $\left[\mathrm{CO}_{2}\right]$ plots has a $\delta^{13} \mathrm{C}$ of about $-20 \%$ o. The isotopic shift caused by the ${ }^{13} \mathrm{C}$ depleted $\mathrm{CO}_{2}$ continuously applied in the elevated $\left[\mathrm{CO}_{2}\right]$ plots allows for distinguishing $\mathrm{C}$ from plant and soil material produced before starting the experiment $\left(\delta^{13} \mathrm{C}\right.$ of $-29.9 \pm 0.2 \%$ and $-27.6 \pm 0.2 \%$ for needles and roots respectively) and plant material produced during the experiment after $1996(41.8 \pm 0.3 \%$ and $-39.7 \pm 0.8 \%$ or needles and roots, respectively; see Matamala et al., 2003; Taneva and Gonzalez-Meler, 2008, for examples). The ${ }^{13} \mathrm{C}$ label has also slowly been incorporated into soil organic matter pools and in soil-respired $\mathrm{CO}_{2}$ (Andrews et al., 1999; Schlesinger and Lichter, 2001; Taneva et al., 2006; Lichter et al., 2008; Taneva and Gonzalez-Meler, 2008). The different rate at which the ${ }^{13} \mathrm{C}$ label is incorporated into respired- $\mathrm{CO}_{2}$ of soils components (Taneva et al., 2006) allow for the separation of root-respired $\mathrm{CO}_{2}$ from SOM-respired $\mathrm{CO}_{2}$ (see below).

\subsection{Growing season soil respiration and litter removal treatment}

During the 2003 and 2004 growing seasons, soil respiration rates were measured with a field-portable infrared gas analyzer (IRGA; LiCor 6400-09, Lincoln, Nebraska, USA) at 12 PVC collars, randomly placed within each FACE plot inserted $3 \mathrm{~cm}$ into the mineral soil and open to rainfall and litterfall, except during measurements. In May 2004, four additional soil collars were installed in each FACE plot, where the litter layer was completely removed down to the mineral soil. A layer of inert fiber glass was placed over the soil in order to reproduce the $\mathrm{CO}_{2}$ diffusivity and moisture content of the removed litter. Soil respiration rates were measured monthly during the growing season of the forest (May-October), both during the day (12:00-14:00 EST) and at night (22:00-00:00 EST). Measurements were made at the times previously determined to capture most of the diurnal variability in soil respiration rates. The six FACE plots were grouped into three blocks, each including one treatment and one control plot. The measurement time in each plot was $\sim 1 \mathrm{~h}$ and, therefore, only one block was measured on a given day, in order to ensure time consistency of measurements. Measurements in all three blocks were carried out on days with comparable environmental conditions and were usually completed within 5-6 days.

\subsection{Stable isotope analysis of soil-respired $\mathrm{CO}_{2}$}

During the 2003 and 2004 growing seasons, soil-respired $\mathrm{CO}_{2}$ samples were collected monthly from collars with and without litter, both during the day and at night, within $24 \mathrm{~h}$ after soil respiration measurements were made (see above). Carbon dioxide gas samples were collected from a LiCor 6400-09 soil chamber into evacuated $120-\mathrm{ml}$ glass flasks, after being passed through a magnesium perchlorate water trap (Still et al., 2003; Trueman and Gonzalez-Meler, 2005; Moore et al., 2008). The $\mathrm{CO}_{2}$ concentration of each sample was measured at the time of sample collection. At least eight gas samples from collars containing litter or no litter layer were collected from each FACE plot at each sampling time. Samples were collected from different collars to avoid alterations of convective patterns of $\mathrm{CO}_{2}$ from soil to air and other recognized problems when collecting soil surface fluxes for building keeling plots (Phillips and Greg, 2001; Trueman and Gonzalez-Meler, 2005; Bowling et al., 2008; Kayler et al., 2010). Different collars were used because previous trials made both in May of 2003 and 2004 showed that the constructed Keeling plots obtained from a single location or multiple nearby collar location were not different (see the Supplement, Still et al., 2003). Gas samples were collected at $\mathrm{CO}_{2}$ concentrations that differed by at least $50 \mathrm{ppm}$ from other samples. Samples were shipped to the University of Illinois at Chicago for stable isotope analysis. In the laboratory, soil-respired $\mathrm{CO}_{2}$ samples were purified by cryogenic 
Table 1. The seasonal average ${ }^{13} \mathrm{C}$ signature of respired $\mathrm{CO}_{2}$ and bulk mass from roots, root-free soil organic matter, and litter from control and treatment plots at FACTS-1. The average values listed here were derived from several day and night field incubations (see methods) for each collar location and for each time soil respiration and keeling plots were made in 2004 (June through September). Average values are expressed in per mil \pm standard error $(n=3)$.

\begin{tabular}{lllll}
\hline & \multicolumn{2}{c}{ Ambient $\left[\mathrm{CO}_{2}\right]$} & \multicolumn{2}{c}{ Elevated $\left[\mathrm{CO}_{2}\right]$} \\
& Respired $\mathrm{CO}_{2}$ & Bulk Mass & Respired $\mathrm{CO}_{2}$ & Bulk Mass \\
\hline Roots & $-29.0 \pm 0.5$ & $-27.6 \pm 0.4$ & $-40.4 \pm 1.0$ & $-39.7 \pm 0.5$ \\
Root-free SOM & $-26.5 \pm 0.1$ & $-26.3 \pm 0.3$ & $-34.5 \pm 0.6$ & $-30.2 \pm 0.1$ \\
Forest floor Litter & $-28.7 \pm 0.4$ & $-27.9 \pm 0.2$ & $-37.9 \pm 0.6$ & $-39.6 \pm 0.3$ \\
\hline
\end{tabular}

extraction before they were analyzed for their stable C isotope composition with a Finnegan Delta Plus XL (Bremen, Germany) isotope ratio mass spectrometer. The $\delta^{13} \mathrm{C}$ of soilrespired $\mathrm{CO}_{2}$, in the absence of atmospheric air, was determined using Keeling Plot analyses (Pataki et al., 2003). The range in $\left[\mathrm{CO}_{2}\right]$ of samples used to construct Keeling Plots was at least $480 \mathrm{ppm}$. Keeling Plot regressions with an $r^{2}$ value of $<0.90$ were excluded from further analysis.

\subsection{Isotopic composition of root-, SOM- and litter-respired $\mathrm{CO}_{2}$}

The isotopic composition of root-, SOM- and litter-respired $\mathrm{CO}_{2}$ was measured (following Hymus et al., 2005 and Trueman and Gonzalez-Meler, 2005) and used as endmembers in order to partition the root, SOM and litter contributions to soil respiration. Throughout the growing season of 2004, soil cores $(0-10 \mathrm{~cm}, 2 \mathrm{~cm}$ diameter) were collected from locations adjacent to collars after respiration and isotope measurements (keeling plots) were done. Top $10 \mathrm{~cm}$ were chosen as it contains more than $90 \%$ of the fine root biomass (Matamala et al., 2003) and has the most changes in pore space soil $\mathrm{CO}_{2}$ concentration (Taneva et al., 2006) and $\mathrm{C}$ mineralization levels (Lichter et al., 2008; Taneva and Gonzalez-Meler, 2008). For endmemeber determination by incubations, roots and leaf litter were removed from the soil immediately after collection. Live fine roots $(<5 \mathrm{~mm}$ diameter) were further rinsed in distilled water of all attached soil. Soil was removed from the litter by hand. In order to determine the $\delta^{13} \mathrm{C}$ of respired $\mathrm{CO}_{2}$, litter, roots, and root-free soil (SOM) collected from each FACE plot were incubated separately in the dark in custom-designed PVC chambers with screw caps (400-ml chambers for soil and litter incubations and 150-ml chambers for root incubation), following Hymus et al. (2005), Trueman and Gonzalez-Meler (2005) and Taneva and Gonzalez-Meler (2008). Incubations were done at soil (root, SOM) and forest floor temperature (litter) at the time of collection. The field incubation system consisted of a pump, a soda lime column placed before the incubation chamber, a desiccant column placed between the chamber and the glass flask, where the respired $\mathrm{CO}_{2}$ was eventually collected, and an IRGA (LiCor 6262, Lincoln, Nebraska, USA). All components of the incubation system were connected to each other with Bev-A-Line ${ }^{\circledR}$ tubing (1/4" outer diameter). Before sample incubation, the chamber, the 150-ml glass flask, and the line were flushed with $\mathrm{CO}_{2}$-free air by pumping dry ambient air through the soda lime column. An Infra Red Gas Analyzer was used to monitor the $\left[\mathrm{CO}_{2}\right]$ of the air in the incubation system and trapped sample. The air-tight chamber remained close with three-way valves (Swagelok, Solon, $\mathrm{OH}, \mathrm{USA}$ ) for an incubation period of 20-30 min, depending on respiration rate. After the incubation and prior to collecting the respired $\mathrm{CO}_{2}$ from each sample, the incubation system was once again flushed with $\mathrm{CO}_{2}$-free air, bypassing the closed incubation chamber, to ensure the lines and flask were free of $\mathrm{H}_{2} \mathrm{O}$ and $\mathrm{CO}_{2}$. Then, valves from the incubation chamber were opened and the $\mathrm{CO}_{2}$-free air carried the sample respired- $\mathrm{CO}_{2}$ into the glass flask, with concentrations ranging from 400 to $1200 \mathrm{ppm}$. Flasks containing the dried gas samples were shipped to the University of Illinois at Chicago for analysis. These incubation experiments were also done at the ambient rings to account for the environmental variability in the isotopic composition of respired $\mathrm{CO}_{2}$ that are independent from the addition of the post treatment isotope label. The $\delta^{13} \mathrm{C}$ value of respired $\mathrm{CO}_{2}$ from roots, litter, and root-free soil from each plot at each sampling time (see Table 1 for averages) was used in the partitioning of soilrespired $\mathrm{CO}_{2}$ into its source components (see below).

\subsection{Partitioning soil-respired $\mathrm{CO}_{2}$ into its $\boldsymbol{R}_{\mathrm{R}}, \boldsymbol{R}_{\mathrm{SOM}}$ and $R_{\mathrm{L}}$ components in the 2004 growing season}

There is a large isotopic difference between the $\mathrm{C}$ that was fixed by the ecosystem after $\mathrm{CO}_{2}$ fumigation started compared to the existing ecosystem $\mathrm{C}$ (see Sect. 2.7 for details). Also the isotope air label in elevated $\mathrm{CO}_{2}$ plots was rapidly incorporated in soil $\mathrm{CO}_{2}$, soil respiration and new roots (days to months; Andrews et al., 1999; Matamala et al., 2003; Taneva et al., 2006), moderately incorporated in existing roots and litter (years; Matamala et al., 2003; Lichter et al., 2008) and slowly into SOM pools (decades; Lichter et al., 2008). However, at this site the isotopic composition of 
static pools does not correspond to the isotopic composition of metabolically active pools (Taneva et al., 2006) and therefore the isotopic composition of respired $\mathrm{CO}_{2}$ from roots, $\mathrm{SOM}$, and forest floor litter need to be measured and used in partitioning mixing models. There is a large isotopic difference between the $\delta^{13} \mathrm{C}$ of respired $\mathrm{CO}_{2}$ form roots and SOM ( $>6$ per mil), but the difference with forest floor litter is too small (within 3 per mil). The litter exclusion experiments enabled us to further partition soil-respired $\mathrm{CO}_{2}$ into $\mathrm{CO}_{2}$ originating from root/rhizosphere respiration $\left(R_{\mathrm{R}}\right)$, litter decomposition $\left(R_{\mathrm{L}}\right)$, and SOM decomposition $\left(R_{\mathrm{SOM}}\right)$. This is because in absence of litter, the $\delta^{13} \mathrm{C}$ of respired $\mathrm{CO}_{2}$ is related to contributions from only roots and SOM to $R_{\mathrm{S}}$ with large isotopic differences. Once the proportions of $R_{\mathrm{R}}$ and $R_{\mathrm{SOM}}$ are known, $R_{\mathrm{L}}$ can be derived from the $\delta^{13} \mathrm{C}$ of $R_{\mathrm{S}}$ measured with litter. Using two mixing equations with two unknowns, the contribution of $R_{\mathrm{R}}, R_{\mathrm{SOM}}$, and $R_{\mathrm{L}}$ to total $R_{\mathrm{S}}$ can then be expressed as follows:

$$
\begin{aligned}
& \delta^{13} \mathrm{C}_{R_{\mathrm{SCO}_{2}}}=a \cdot \delta{ }^{13} \mathrm{C}_{\mathrm{root} \mathrm{CO}}+b \cdot \delta^{13} \mathrm{C}_{\mathrm{SOM} \mathrm{CO}_{2}} \\
& +(1-(a+b)) \cdot \delta^{13} \mathrm{C}_{\text {litter } \mathrm{CO}_{2},}
\end{aligned}
$$

where the fraction of root-respired $\mathrm{CO}_{2}(a)$ was determined from Eq. (4), $b$ is the fraction of soil-respired $\mathrm{CO}_{2}$ produced by SOM decomposition, and the remaining $\mathrm{CO}_{2}$ in $R_{\mathrm{S}}$, determined as $(1-(a+b))$, represents $\mathrm{CO}_{2}$ produced in forest floor litter decomposition.

Assuming that the ratio of $R_{\mathrm{R}}$ to $R_{\mathrm{SOM}}$ in the plots without litter is the same as that in plots with litter, the fractions of $R_{\mathrm{R}}$ and $R_{\mathrm{SOM}}$ in plots without litter (nl) can be expressed as follows:

$$
\begin{aligned}
& \delta^{13} \mathrm{C}_{\mathrm{nl} \mathrm{CO}}=(a /(a+b)) \cdot \delta^{13} \mathrm{C}_{\text {root } \mathrm{CO}_{2}}+(b /(a+b)) \\
& \cdot \delta^{13} \mathrm{C}_{\mathrm{SOM} \mathrm{CO}},
\end{aligned}
$$

where $a$ represents the fraction of root-respired $\mathrm{CO}_{2}$ in $R_{\mathrm{S}}$, $b$ is the fraction of SOM decomposition in $R_{\mathrm{S}}$ (as in Eq. 3), $\delta^{13} \mathrm{C}_{\mathrm{nl} \mathrm{CO}}$ is the $\delta^{13} \mathrm{CO}_{2}$ from collars with no litter (from Keeling Plot analyses), $\delta^{13} \mathrm{C}_{\text {root }}$ is the $\delta^{13} \mathrm{C}$ of root-respired $\mathrm{CO}_{2}$ (from root incubations), and $\delta^{13} \mathrm{C}_{\mathrm{SOM}}$ is the $\delta^{13} \mathrm{C}$ measured with litter- and root-free soil incubations (incubation methods described in Sect. 2.5).

To calculate the actual respiration rate each of these components contribute to total $R_{\mathrm{S}}$, the fractional values of $a, b$, and $(1-(a+b))$ calculated over the growing season were multiplied by the measured $R_{\mathrm{S}}$ rate for each of the 12 collars per plot at a given time of the growing season when measurements were made. Then the $12 R_{\mathrm{S}}$ locations per plot were averaged for each FACE ring, the replication unit, before the treatment average was measured $(n=3)$. We report here the $R_{\mathrm{L}}$ rates calculated with the isotope method for consistency and because of statistical power as they were calculated from 12 locations per plot (as oppose to 4 locations per plot using the $R_{\mathrm{S}}$ and $R_{\mathrm{nl}}$ difference). Also $R_{\mathrm{L}}$ measured as a residual from the litter exclusion experiments based on 4 replicates introduce artifacts due to variable forest floor mass.

\subsection{Determination of pre- and post-treatment $\mathrm{C}$ in $\boldsymbol{R}_{\mathrm{S}}$}

Soil-respired $\mathrm{CO}_{2}$ can be partitioned into $\mathrm{C}$ that was photosynthetically fixed since the beginning of $\mathrm{CO}_{2}$ fumigation (referred to as "post-treatment" $\mathrm{C}$ ) and $\mathrm{C}$ assimilated under ambient $\left[\mathrm{CO}_{2}\right]$ before fumigation started in September, 1996 (referred to as "pre-treatment" C). We used the following two end-member mixing equation:

$\delta^{13} \mathrm{C}_{R_{\mathrm{S}} \mathrm{CO}_{2}}=f \cdot \delta^{13} \mathrm{C}_{\text {pre-tr }}+(1-f) \cdot \delta^{13} \mathrm{C}_{\text {post-tr }}$

where $\delta^{13} \mathrm{C}_{R_{\mathrm{S}} \mathrm{CO}_{2}}$ is the measured $\delta^{13} \mathrm{C}$ of soil-respired $\mathrm{CO}_{2}$ at a given time, $\delta^{13} \mathrm{C}_{\text {post-tr }}$ is the end-member for posttreatment $\mathrm{C}, \delta^{13} \mathrm{C}_{\text {pre-tr }}$ is the end-member for pre-treatment $\mathrm{C}$ (usually separated by about 12 per mil) and $f$ represents the fraction of pre-treatment $\mathrm{C}$ in soil $\mathrm{CO}_{2}$ (Taneva et al., 2006). This partitioning was done for all collection times during the 2003 and 2004 growing seasons.

The $\delta^{13} \mathrm{C}_{\text {pre-tr }}$ is determined by directly measuring $\delta^{13} \mathrm{C}_{R_{\mathrm{S}} \mathrm{CO}_{2}}$ in the control plots of the experiment at time of measurements. This measured value incorporates respiration from both recalcitrant and labile soil $\mathrm{C}$ pools under ambient $\mathrm{CO}_{2}$ conditions. The $\delta^{13} \mathrm{C}$ of recalcitrant soil $\mathrm{C}$ pools has little or no seasonal variation (Balesdent and Mariotti, 1996) and therefore the $\delta^{13} \mathrm{C}$ of respired- $\mathrm{CO}_{2}$ from this pool will not vary. Therefore, any seasonal variability in $\delta^{13} \mathrm{C}$ of soil-respired $\mathrm{CO}_{2}$ in the control plots is due to differences in the signature of respired $\mathrm{CO}_{2}$ from labile soil $\mathrm{C}$ pools (i.e. root/rhizosphere respiration), reflecting, for instance, seasonal fluctuations in photosynthetic discrimination. There are two tested conditions that allow us to use ambient signature of soil-respired $\mathrm{CO}_{2}$ in the calculations: (1) the $\delta^{13} \mathrm{C}$ of the atmosphere in the $\mathrm{CO}_{2}$-enriched plots was changed by a constant value $E$ at the beginning of the experiment, and (2) the photosynthetic discrimination against ${ }^{13} \mathrm{C}$ is very similar under ambient and elevated $\left[\mathrm{CO}_{2}\right]$ due to conserved $\mathrm{C}_{i} / \mathrm{C}_{a}$ for concentrations ranges below $\sim 700 \mu \mathrm{l}^{-1}$ (Ellsworth, 1999; Katul et al., 2010) making the difference in $\delta^{13} \mathrm{C}$ of new photosynthate in the control and treatment plots to approximate $E$. Therefore, the end-member for the $\delta^{13} \mathrm{C}$ of soil-respired $\mathrm{CO}_{2}$ in the enriched plots $\left(\delta^{13} \mathrm{C}_{\text {post-tr }}\right)$ can be derived by subtracting $E$ from the measured $\delta^{13} \mathrm{C}_{\text {pre-tr }}$ and Eq. (3) can be rearranged as follows:

$f=\left(\delta^{13} \mathrm{C}_{R_{\mathrm{S}} \mathrm{CO}_{2}}-\delta^{13} \mathrm{C}_{\text {post-tr }}\right) / E$

where $E$ is measured to be $11.82 \pm 0.43 \%$ based on: (i) the 1996-2004 plot average $\left[\mathrm{CO}_{2}\right]$ and $\delta^{13} \mathrm{C}$ of fumigation $\mathrm{CO}_{2}$; (ii) change in isotopic composition of new leaf tissue between ambient and elevated $\left[\mathrm{CO}_{2}\right]$; (iii) change in isotopic composition of new in-growth root tissue between ambient and elevated $\left[\mathrm{CO}_{2}\right]$; (iv) the difference in the isotopic composition in root-respired $\mathrm{CO}_{2}$ between ambient and elevated $\left[\mathrm{CO}_{2}\right]$. This value of $\sim 12 \%$ o has been widely applied for isotope mixing models at the site (e.g. Andrews et al., 1999; Schlesinger and Lichter, 2001; Matamala et al., 2003; Bernhardt et al., 2006; Lichter et al., 2008). These pre- and 
post-treatment $\mathrm{C}$ partitioning were done for the growing seasons of 2003 and 2004.

For the growing season of 2004, we used pre-treatment C flux to further partition $R_{\mathrm{S}}$. In 2004, pre-treatment $\mathrm{CO}_{2}$ efflux originated from soil $\mathrm{C}$ pools that were at least $8 \mathrm{yr}$. At the study site, the mean residence times of root and forest floor $\mathrm{C}$ are about 4 and $2.5 \mathrm{yr}$, respectively (Matamala et al., 2003; Lichter et al., 2008). It is unlikely that substantial amounts of storage carbohydrates contributed to $R_{\mathrm{R}}$ after 8 yr. It is also unlikely that forest floor litter respiration contributed substantially to pre-treatment $\mathrm{C}$ because litter mass would have been replaced by about $95 \%$ ( 3 times the turnover time). Therefore, it can be assumed that most of the fraction of soil-respired $\mathrm{CO}_{2}$ (i.e. in total $R_{\mathrm{S}}$ ) derived from pre-treatment $\mathrm{C}$ pools (i.e. $\mathrm{C}$ assimilated before 1996; Eq. 4) originated from SOM decomposition (including some root litter decomposition). Therefore, the contributions of $\mathrm{C}_{\text {pre-tr }}$ (oxidation of soil pools older than $8 \mathrm{yr}$ ) and $\mathrm{C}_{\text {post-tr }}$ were applied to the rate of SOM decomposition.

\subsection{Canopy air temperature and soil temperature and moisture}

Continuous temperature measurements were taken at lower canopy air and at $10 \mathrm{~cm}$ soil depth in each FACE plot, using Siemens Type M 841/S1 thermistors at $30 \mathrm{~min}$ interval averages. Continuous soil moisture measurements were taken with a Campbell Scientific Model CS 615 probes (Logan, Utah, USA) consisting of two $30 \mathrm{~cm}$ long metal rods, over which each moisture measurement is integrated. Soil temperature and moisture measurements were taken every 5 or $30 \mathrm{~s}$, averaged over $30 \mathrm{~min}$ intervals and automatically logged with Campbell 21X or 23X data loggers.

The rate of total $R_{\mathrm{S}}$ and each $R_{\mathrm{S}}$ component was plotted against soil temperature and soil moisture at each measurement date and time (regressions not shown). Litter respiration was also plotted against lower canopy air temperature. The relationship between soil temperature and $R_{\mathrm{S}}$ and its components was determined by fitting a second-order exponential growth function to the data, according to the equation $f=a e^{b x}$ (Lloyd and Taylor, 1994). The relationship between $R_{\mathrm{S}}$ and each $R_{\mathrm{S}}$ component and soil moisture was determined by fitting linear functions to the data, according to the equation $f=y_{0}+a x$ (Orchard and Cook, 1983).

\subsection{Statistical and error sensitivity analyses}

Temporal variability in $R_{\mathrm{S}}$ and $R_{\mathrm{S}}$ components was examined with mixed-effects and random-effects regression analyses (Proc Mixed, SAS v. 9.1, Cary, NC). Unlike regular regressions, random-effects regression does not assume each measurement is independent, but assumes data are dependent on clusters, here FACE plots (Hedeker et al., 1994). This method also allows for analyses of unbalanced data (i.e. different observations at different clusters or time series). With balanced datasets, this method is analogous to nested analyses of variance of mixed-model regressions. Rates of $R_{\mathrm{S}}$ in 2003 and 2004 were fitted to a regression model with $\mathrm{CO}_{2}$ treatment, time of day, month, and year as covariates, and interactions of $\mathrm{CO}_{2}$ treatment with time of day and year. For 2004, regression models with effects for month, time of day (day or night), month by time of day interaction, and a random effect for plot were fitted to root versus non root $R_{\mathrm{S}}$ and to $R_{\mathrm{R}}, R_{\mathrm{SOM}}, R_{\text {pre-tr }}, R_{\text {post-tr }}$, and $R_{\mathrm{L}}$ rates.

A sensitivity analyses was made to estimate the error propagation of the calculated $R_{\mathrm{R}}, R_{\mathrm{SOM}}$ and $R_{\mathrm{L}}$ components of $R_{\mathrm{S}}$ to endmember determinations. Rapid variations in the isotopic composition of respired $\mathrm{CO}_{2}$ may induce an error in the mixing models used here. For this sensitivity analyses we applied a $\pm 1.5 \%$ o to the root, $\mathrm{SOM}$ and litter respired $\mathrm{CO}_{2}$ determinations from the incubation chambers. The isotopic composition of, particularly root respiration, can vary rapidly depending on, for instance, photosynthetic conditions. The sensitivity analyses were performed to account for this variability and for potential sampling biases and propagated errors during calculations. To minimize errors originating from $R_{\mathrm{S}}$, we averaged the resulting $R_{\mathrm{R}}, R_{\mathrm{L}}$ and $R_{\mathrm{SOM}}$ partitioning of $R_{\mathrm{S}}$ at 12 locations within each replication unit (i.e. each FACE ring). Each per ring average was then used to obtain the treatment average $(n=3)$. We performed these analyses and approaches for each month and time of day we calculated the root litter and SOM components of $R_{\mathrm{S}}$.

\section{Results}

\subsection{Seasonal and interannual variability of $R_{\mathrm{S}}$}

We measured $R_{\mathrm{S}}$ for the ambient and elevated $\mathrm{CO}_{2}$ plots for the growing seasons of 2003 and 2004. Rates of $R_{\mathrm{S}}$ differed significantly in the two years of study $(p<0.0001)$; $R_{\mathrm{S}}$ rates in 2004 were on average $16 \%$ higher than $R_{\mathrm{S}}$ rates in 2003 (Fig. 1). Rates of $R_{\mathrm{S}}$ in both treatment and control plots showed seasonal variability in both years of study ( $p<0.0001)$ with higher $R_{\mathrm{S}}$ in the middle of the growing season (Fig. 1). Soil respiration rates were not significantly stimulated by ecosystem exposure to elevated $\left[\mathrm{CO}_{2}\right]$ during $2003(p>0.5)$, but there was a significant $\mathrm{CO}_{2}$ treatment effect on $R_{\mathrm{S}}$ in 2004 ( $p<0.03$; Fig. 1). Rates of $R_{\mathrm{S}}$ were on average $14 \%$ higher under elevated $\left[\mathrm{CO}_{2}\right]$ in 2004 relative to ambient $\mathrm{CO}_{2}$ conditions. The magnitude of the $\mathrm{CO}_{2}$ treatment effect on $R_{\mathrm{S}}$ varied diurnally and seasonally in the two years of measurement (Fig. 1). Daytime $R_{\mathrm{S}}$ rates under elevated $\left[\mathrm{CO}_{2}\right]$ in 2003 were between $1 \%$ (in August, $p>0.8$ ) and $20 \%$ (in September, $p<0.1$ ) higher than daytime $R_{\mathrm{S}}$ rates under ambient $\left[\mathrm{CO}_{2}\right]$. Nighttime $R_{\mathrm{S}}$ rates in 2003 were between $5 \%$ lower (in August, $p>0.5$ ) and $10 \%$ higher (in September, $p>0.5$ ) than nighttime rates under ambient $\left[\mathrm{CO}_{2}\right]$. In 2004 , the enhancement of daytime $R_{\mathrm{S}}$ rates in the $\mathrm{CO}_{2}$ treatment plots was between $9 \%$ (in August, 


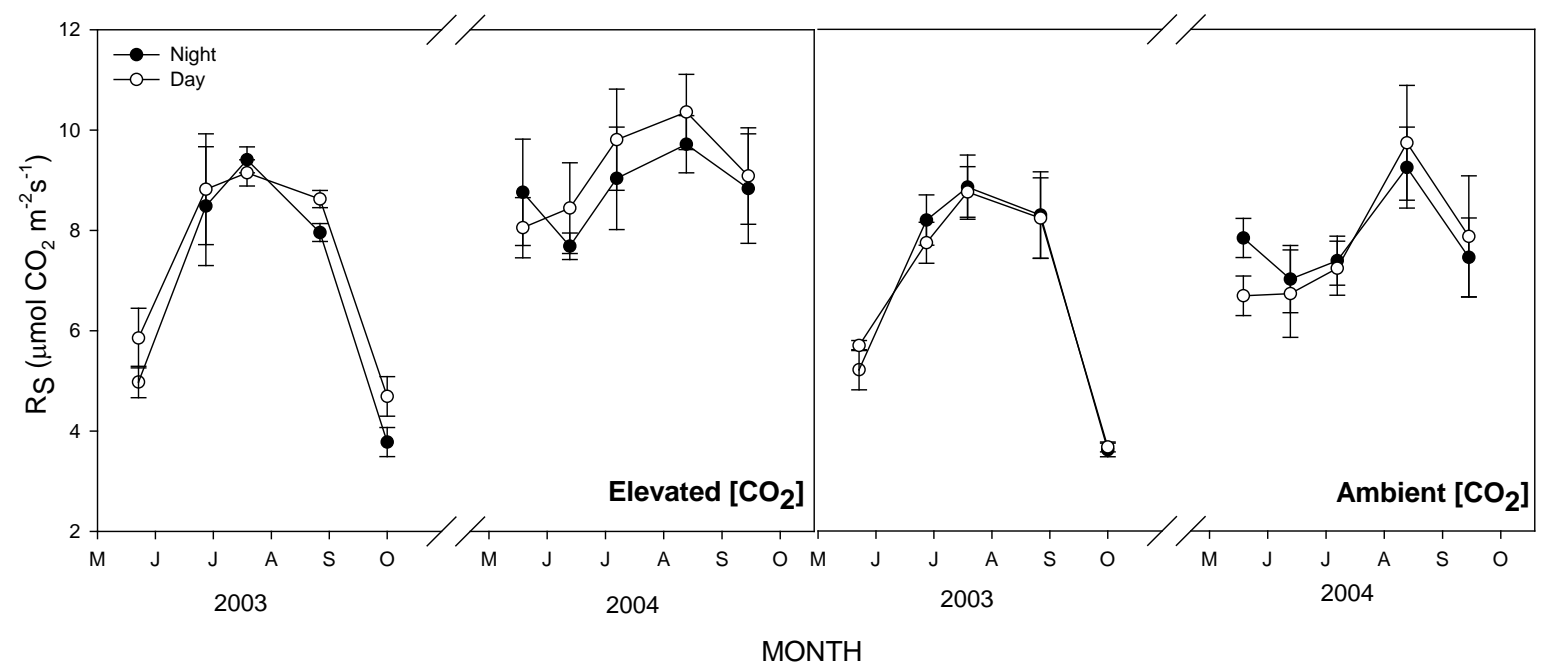

Fig. 1. The rates of soil respiration at FACTS-1 under ambient and elevated $\left[\mathrm{CO}_{2}\right]$ during the growing seasons of 2003 and 2004 and measured at night (filled symbols) and daytime (open symbols). Values are means \pm standard error $(n=3)$.

$p<0.1$ ) and $21 \%$ (in July, $p<0.002$ ). Nighttime $R_{\mathrm{S}}$ rates under elevated $\left[\mathrm{CO}_{2}\right]$ in 2004 were between $5 \%$ (in August, $p>0.4$ ) and $17 \%$ (in July, $p<0.02$ ) higher than $R_{\mathrm{S}}$ rates in the control plots.

\subsection{Nighttime and daytime $R_{\mathrm{S}}$}

Daytime and nighttime $R_{\mathrm{S}}$ rates were not significantly different during the two years of measurements $(p>0.2)$ under either ambient or elevated $\left[\mathrm{CO}_{2}\right]$, with the exception of a significant $\mathrm{CO}_{2}$ treatment $\times$ time interaction in $2003(p<0.04$; Fig. 1). In 2003, daytime $R_{\mathrm{S}}$ rates were on average $6 \%$ higher than nighttime rates under elevated $\left[\mathrm{CO}_{2}\right]$, although at ambient $\left[\mathrm{CO}_{2}\right]$ conditions seasonal daytime and nighttime $R_{\mathrm{S}}$ rates differed by less than $1 \%$. In 2004 at elevated $\left[\mathrm{CO}_{2}\right]$, daytime $R_{\mathrm{S}}$ rates were $3 \%$ higher than nighttime rates ( $p>$ $0.3)$. At ambient $\left[\mathrm{CO}_{2}\right]$ daytime rates were $3 \%$ lower than nighttime rates under ambient $\left[\mathrm{CO}_{2}\right](p>0.2)$. Daytime $R_{\mathrm{S}}$ rates were $9 \%$ higher in 2003 and $17 \%$ higher in 2004 under elevated $\left[\mathrm{CO}_{2}\right]$ relative to ambient $\left[\mathrm{CO}_{2}\right](p<0.1$; Fig. 1$)$. Nighttime rates of $R_{\mathrm{S}}$ were $2 \%$ and $12 \%$ greater under elevated $\left[\mathrm{CO}_{2}\right]$ in 2003 and 2004, respectively ( $p>0.1$; Fig. 1).

\subsection{Soil respiration components under elevated $\left[\mathrm{CO}_{2}\right]$}

The continuous whole ecosystem C-isotope label in forest plots exposed to elevated $\left[\mathrm{CO}_{2}\right]$ (beginning September 1996) offered the opportunity to partitioning soil-respired $\mathrm{CO}_{2}$ into several source components at the 7 th and 8 th growing seasons after high $\mathrm{CO}_{2}$ exposure. This isotope partitioning is not possible at ambient conditions and therefore the following analyses are restricted to the treatment plots only. Soil respiration was partitioned into two C-age components in 2003 and 2004. In 2004, $R_{\mathrm{S}}$ was further partitioned into 4 source components.

\subsubsection{Post-treatment $C$ in $R_{S}$ in 2003 and 2004}

Pre-treatment (C fixed by the ecosystem prior to September 1996) and post-treatment C (C fixed by the ecosystem after September 1996) partitioning of respired $\mathrm{CO}_{2}$ by soils was done during the growing seasons of 2003 (7th growing season of isotope label exposure) and 2004 (8th growing season of isotope labeling) as in Taneva et al. (2006). Post-treatment C flux was the largest flux component in $R_{\mathrm{S}}$ and showed no significant diurnal variation (Fig. 2). Post-treatment $C$ flux had a strong seasonal pattern during the growing season of 2003 (Fig. 2a) where $R_{\text {post-tr was higher in the June-August }}$ period than in previous and posterior months. This seasonal variation was less pronounced during the growing season of 2004 where rates of $R_{\text {post-tr }}$ were higher than in 2003 at the beginning and the end of the growing season.

In 2003, the contribution of post-treatment $C$ (from autotrophic and heterotrophic sources) to daytime $R_{\mathrm{S}}$ ranged from 58.6 $\pm 8.3 \%$ in May to $87.5 \pm 5.1 \%$ in July (Fig. 2). At night, the contribution of post-treatment $\mathrm{C}$ to $R_{\mathrm{S}}$ ranged from $56.2 \pm 12.9 \%$ in June to $84.0 \pm 3.8 \%$ in August. In 2004, the daytime flux and contribution of post-treatment $\mathrm{C}$ to $R_{\mathrm{S}}$ was higher than in $2003(p<0.04)$ and ranged from $82.5 \pm 9.1 \%$ in May to $89.9 \pm 3.5 \%$ in July (Fig. 2). The contribution of post-treatment $\mathrm{C}$ to nighttime $R_{\mathrm{S}}$ was less than during the day and ranged from $76.6 \pm 9.1 \%$ in August to $84.8 \pm 6.3 \%$ in May (Fig. 2).

\subsubsection{Root/rhizosphere respiration $\left(R_{R}\right)$ in 2004}

In 2004, $R_{\mathrm{R}}$ had a seasonal average of $2.81 \pm 0.50 \mu \mathrm{mol} \mathrm{CO}$ $\mathrm{m}^{-2} \mathrm{~s}^{-1}$ during the day and $3.04 \pm 0.66 \mu \mathrm{mol} \mathrm{CO} \mathrm{CO}_{2} \mathrm{~m}^{-2} \mathrm{~s}^{-1}$ at night (Fig. 3; Table 2). Overall daytime and nighttime $R_{\mathrm{R}}$ rates were not significantly different $(p>0.3)$, despite 


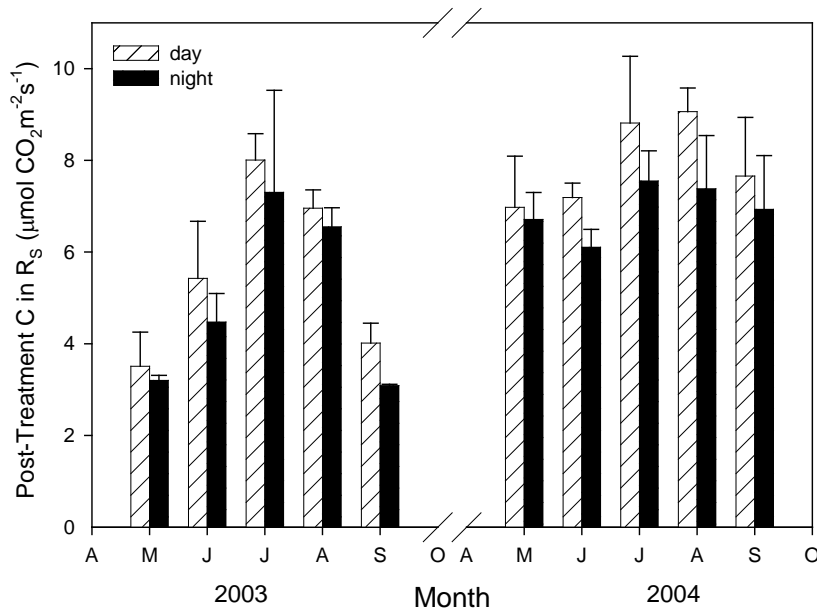

Fig. 2. The amount of post-treatment belowground $\mathrm{C}$ ( $\mathrm{C}$ fixed after September 1996) to daytime (open bars) and nighttime (closed bars) soil respiration rates during the growing seasons of 2003 and 2004 at FACTS-1. Values are means $(n=3) \pm$ standard error.

significant differences in diel rates in August. Overall, $R_{\mathrm{R}}$ rates were $8 \%$ lower during the day than at night (Table 2). Significantly higher rates of $R_{\mathrm{R}}$ were observed in the middle of the season (July and August) relative to rates early or late in the season (June and September), both during the day $(36 \% ; p<0.001)$ and at night $(39 \% ; p<0.0001)$. These differences were mostly due to much lower daytime $R_{\mathrm{R}}$ rates in September and much higher nighttime rates in August, relative to the rest of the season (Table 2). Daytime and nighttime $R_{\mathrm{R}}$ rates in the middle of the season were also significantly different from those early or late in the season $(p<0.0001)$. The average contribution of $R_{\mathrm{R}}$ to total $R_{\mathrm{S}}$ was $29.7 \pm 5.3 \%$ during the day, ranging from $14.1 \pm 4.4 \%$ in September to $36.8 \pm 4.1 \%$ in June (Table 2). At night, the average contribution of $R_{\mathrm{R}}$ to total $R_{\mathrm{S}}$ was $33.7 \pm 5.9 \%$, ranging from $26.6 \pm 4.5 \%$ in September to $51.4 \pm 3.5 \%$ in August (Table 2).

\subsubsection{Litter decomposition $\left(R_{\mathrm{L}}\right)$}

In 2004, $R_{\mathrm{L}}$ had a seasonal average of $2.56 \pm$ $0.99 \mu \mathrm{mol} \mathrm{CO}_{2} \mathrm{~m}^{-2} \mathrm{~s}^{-1}$ during the day and $1.16 \pm$ $0.57 \mu \mathrm{mol} \mathrm{CO}_{2} \mathrm{~m}^{-2} \mathrm{~s}^{-1}$ at night (Fig. 3; Table 2). Overall, daytime $R_{\mathrm{L}}$ rates were significantly different from nighttime rates $(p<0.0001)$, despite non-significant differences in diel rates in June and July (Fig. 3). On average, daytime $R_{\mathrm{L}}$ rates were $55 \%$ higher than nighttime $R_{\mathrm{L}}$ rates. Neither daytime nor nighttime rates of $R_{\mathrm{L}}$ showed seasonal variability $(p>0.2)$ in 2004.

The average contribution of $R_{\mathrm{L}}$ to total $R_{\mathrm{S}}$ was $25.7 \pm 10.5 \%$ during the day, ranging from $0 \%$ in June to $51.4 \pm 6.7$ in September (Table 2). At night, the average contribution of $R_{\mathrm{L}}$ to total $R_{\mathrm{S}}$ was $12.4 \pm 6.2 \%$, ranging from $0 \%$ in June to $24.3 \pm 6.2 \%$ in July (Table 2 ).

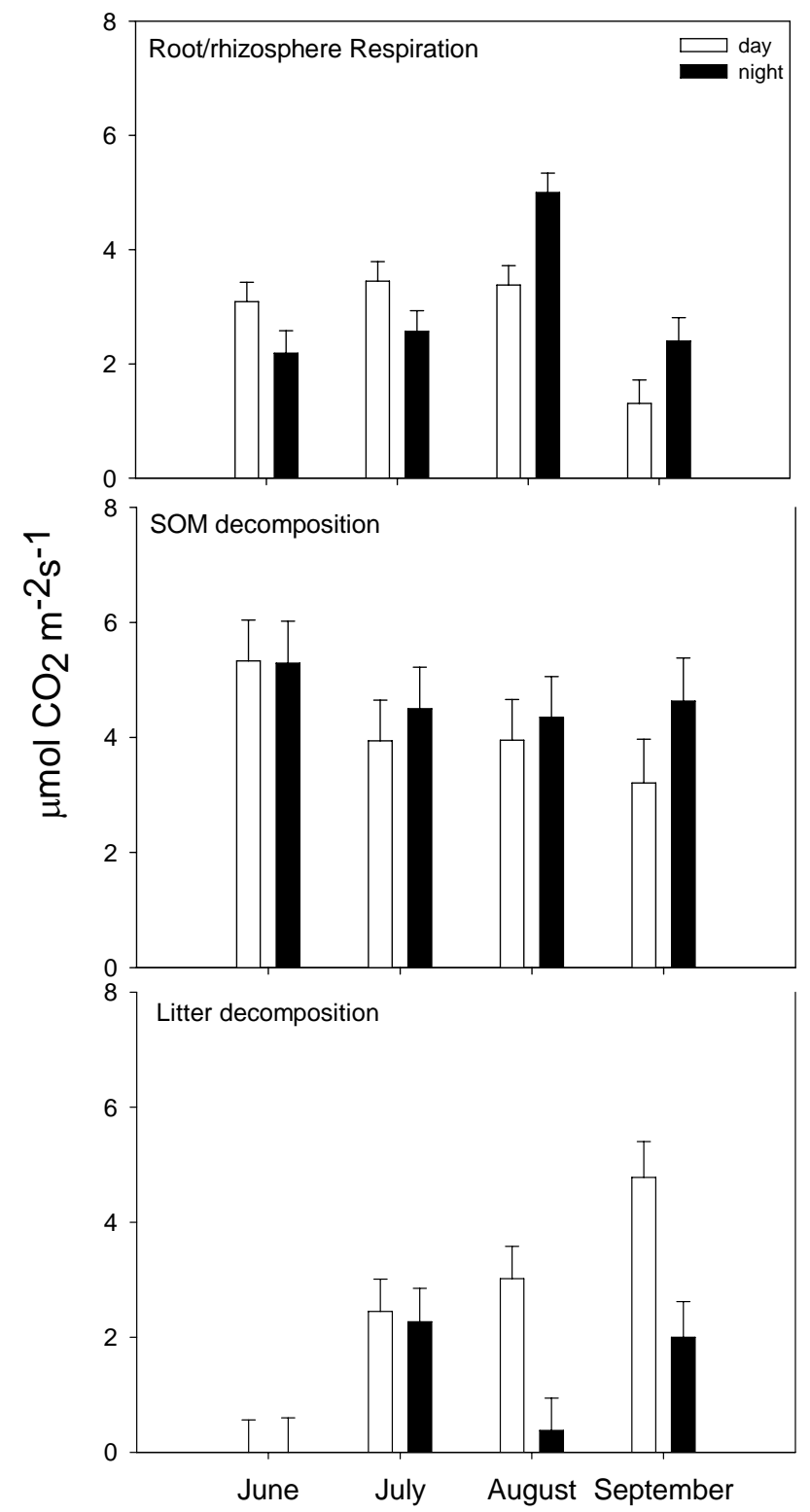

Fig. 3. The rates of the root, soil organic matter, and litter respiration components of soil respiration during the day (open bars) and at night (closed bars) in 2004 at FACTS-1. Values are means $(n=3)$ \pm standard error.

\subsubsection{SOM decomposition $\left(\boldsymbol{R}_{\mathrm{SOM}}\right)$}

In $2004, R_{\mathrm{SOM}}$ had a seasonal average of $4.11 \pm$ $0.44 \mu \mathrm{mol} \mathrm{CO}_{2} \mathrm{~m}^{-2} \mathrm{~s}^{-1}$ during the day and $4.69 \pm$ $0.21 \mu \mathrm{mol} \mathrm{CO} \mathrm{C}_{2} \mathrm{~m}^{-2} \mathrm{~s}^{-1}$ at night (Fig. 3; Table 2). There were significant differences in daytime and nighttime $R_{\mathrm{SOM}}$ rates $(p<0.02)$, mostly because of significant differences between daytime and nighttime $R_{\text {SOM }}$ rates in September ( $p<0.01$; Fig. 3 ). Overall, daytime $R_{\mathrm{SOM}}$ rates were $14 \%$ lower than nighttime $R_{\mathrm{SOM}}$ rates. Significantly higher rates of $R_{\mathrm{SOM}}$ were observed early in the season (June and July) 
Table 2. The $\mathrm{CO}_{2}$ efflux rates and the relative contribution of root $\left(R_{\mathrm{R}}\right)$, soil organic matter $\left(R_{\mathrm{SOM}}\right)$, litter $\left(R_{\mathrm{L}}\right)$ and pre-treatment $\mathrm{C}$ (fixed by the ecosystem up to the year $\left.1996 ; R_{\text {Pre-tr C }}\right)$ components of soil respiration during the day and at night in treatment plots at FACTS-1 over the growing season of 2004. Respiration rates are expressed in $\mu \mathrm{mol} \mathrm{CO} \mathrm{CO}^{-2} \mathrm{~s}^{-1}$ and show average values $(n=3) \pm$ standard error.

\begin{tabular}{|c|c|c|c|c|c|c|c|c|}
\hline FLUX: & $R_{\mathrm{R}}$ & $\% R_{\mathrm{R}}$ & $R_{\mathrm{SOM}}$ & $\% R_{\mathrm{SOM}}$ & $R_{\mathrm{L}}$ & $\% R_{\mathrm{L}}$ & $R_{\text {Pre-trC }}$ & $\% R_{\text {Pre-tr }} \mathrm{C}$ \\
\hline \multicolumn{9}{|l|}{ DAY } \\
\hline June & $3.09 \pm 0.34$ & $36.8 \pm 4.1$ & $5.33 \pm 0.71$ & $63.5 \pm 8.4$ & $0.0 \pm 0.6$ & $0.0 \pm 6.7$ & $1.24 \pm 0.47$ & $14.8 \pm 5.6$ \\
\hline July & $3.45 \pm 0.34$ & $35.1 \pm 3.5$ & $3.94 \pm 0.71$ & $40.1 \pm 7.2$ & $2.45 \pm 0.56$ & $24.8 \pm 5.7$ & $0.95 \pm 0.47$ & $9.7 \pm 4.7$ \\
\hline August & $3.38 \pm 0.34$ & $32.6 \pm 3.3$ & $3.95 \pm 0.71$ & $38.2 \pm 6.8$ & $3.02 \pm 0.56$ & $29.2 \pm 5.4$ & $1.21 \pm 0.47$ & $11.7 \pm 4.5$ \\
\hline September & $1.31 \pm 0.41$ & $14.1 \pm 4.4$ & $3.21 \pm 0.76$ & $34.5 \pm 8.0$ & $4.78 \pm 0.62$ & $51.4 \pm 6.7$ & $1.72 \pm 0.48$ & $18.5 \pm 5.1$ \\
\hline \multicolumn{9}{|l|}{ NIGHT } \\
\hline June & $2.19 \pm 0.39$ & $29.3 \pm 5.2$ & $5.29 \pm 0.73$ & $70.8 \pm 9.7$ & $0.0 \pm 0.6$ & $0.0 \pm 8.0$ & $1.11 \pm 0.47$ & $14.9 \pm 6.3$ \\
\hline July & $2.57 \pm 0.36$ & $27.5 \pm 3.9$ & $4.50 \pm 0.72$ & $48.2 \pm 7.7$ & $2.27 \pm 0.58$ & $24.3 \pm 6.2$ & $1.70 \pm 0.47$ & $18.2 \pm 5.0$ \\
\hline August & $5.00 \pm 0.34$ & $51.4 \pm 3.5$ & $4.35 \pm 0.71$ & $44.7 \pm 7.3$ & $0.38 \pm 0.56$ & $3.9 \pm 5.8$ & $2.17 \pm 0.47$ & $22.2 \pm 4.8$ \\
\hline September & $2.40 \pm 0.41$ & $26.6 \pm 4.5$ & $4.63 \pm 0.75$ & $51.2 \pm 8.2$ & $2.00 \pm 0.62$ & $22.1 \pm 6.9$ & $2.24 \pm 0.48$ & $24.8 \pm 5.3$ \\
\hline
\end{tabular}

relative to later in the season (August and September) during the day $(23 \% ; p<0.003)$, mostly because of high $R_{\mathrm{SOM}}$ rates in June (Fig. 3; Table 2); there were no significant differences between early- and late-season nighttime $R_{\mathrm{SOM}}$ rates $(p>0.2)$.

The average relative contribution of $R_{\mathrm{SOM}}$ to total $R_{\mathrm{S}}$ was $44.1 \pm 6.6 \%$ during the day, ranging from $34.5 \pm 8.0 \%$ in September to $63.5 \pm 8.4 \%$ in June (Table 2). At night, the average contribution of $R_{\mathrm{SOM}}$ to total $R_{\mathrm{S}}$ was $53.7 \pm 5.8 \%$, ranging from $44.7 \pm 7.3 \%$ in August to $70.8 \pm 9.7 \%$ in June (Table 2).

\subsection{Partitioning of $\boldsymbol{R}_{\mathrm{H}}\left(\boldsymbol{R}_{\mathrm{SOM}}+\boldsymbol{R}_{\mathrm{L}}\right)$ into pre- and post-treatment components}

It is unlikely that C fixed prior to 1996 will contribute to autotrophic respiration during the growing season of 2004 . Therefore, all pretreatment $\mathrm{C}$ is likely to originate from $R_{\mathrm{H}}$ $\left(R_{\mathrm{SOM}}+R_{\mathrm{L}}\right)$ during decomposition. The mean residence time of forest floor $\mathrm{C}$ is $2.5 \mathrm{yr}$ (Lichter et al., 2008) and by 2004 the forest floor pool would have been replaced by about $95 \%$. Accordingly pretreatment $\mathrm{C}$ could contribute to no more than $20 \%$ of total $R_{\mathrm{L}}$ rates, but pre-treatment $\mathrm{C}$ from $R_{\mathrm{L}}$ contributed by $5 \%$ of total pre-treatment $\mathrm{C}$ efflux in $R_{\mathrm{S}}$. Because most of the pre-treatment $\mathrm{C}$ in soil $\mathrm{CO}_{2}$ efflux originated from $R_{\mathrm{SOM}}, R_{\mathrm{SOM}}$ was further distinguished between two age pools at the elevated $\left[\mathrm{CO}_{2}\right]$ plots during 2004: pre-treatment $\mathrm{C}$ consisting of $\mathrm{C}$ fixed by the ecosystem prior to September 1996 (>8 yr old), and post-treatment $\mathrm{C}$, assimilated after fumigation began ( $<8 \mathrm{yr}$ old). In 2004 , the seasonal average rate of post-treatment SOM decomposition was $2.83 \pm 0.53 \mu \mathrm{mol} \mathrm{CO} \mathrm{Cm}^{-2} \mathrm{~s}^{-1}$ during the day and $2.89 \pm 0.45 \mu \mathrm{mol} \mathrm{CO}_{2} \mathrm{~m}^{-2} \mathrm{~s}^{-1}$ at night (Fig. 4). The seasonal average rate of pre-treatment SOM decomposition was $1.28 \pm 0.16$ and $1.81 \pm 0.26 \mu \mathrm{mol} \mathrm{CO}_{2} \mathrm{~m}^{-2} \mathrm{~s}^{-1}$ for day and night, respectively (Fig. 4).
Overall rates of post-treatment SOM-C decomposition did not significantly differ between day and night $(p>0.7$; Fig. 4). Higher rates were seen earlier in the season (June and July), both during the day $(40 \%, p<0.0001)$ and at night $(34 \%, p<0.001)$. Unlike post-treatment SOM decomposition, the rates of pre-treatment SOM decomposition differed significantly between day and night $(p<0.0001)$, despite non-significant differences in June $(p>0.4)$. Nighttime rates of pre-treatment $R_{\text {SOM }}$ were about $29 \%$ higher than its daytime rates (Table 2). Seasonal variability in the decomposition of pre-treatment SOM was also significant with rates earlier in the season (June and July) lower than rates later in the season (August and September), both during the day $(25 \%, p<0.005)$ and at night $(36 \%, p<0.0001)$.

The average contribution of post-treatment SOM decomposition to total $R_{\mathrm{S}}$ was $30.4 \pm 6.8 \%$ during the day, ranging from $16.2 \pm 5.4 \%$ in September to $48.6 \pm 5.6 \%$ in June (Table 2). The average relative contribution of pre-treatment SOM decomposition to total $R_{\mathrm{S}}$ was $13.7 \pm 1.9 \%$ during the day, ranging from $9.7 \pm 4.7 \%$ in July to $18.5 \pm 5.1 \%$ in September (Table 2). At night, the average contribution of post-treatment $R_{\mathrm{SOM}}$ to total $R_{\mathrm{S}}$ was $33.7 \pm 7.5 \%$, ranging from $22.5 \pm 4.8 \%$ in August to $55.9 \pm 6.5 \%$ in June (Table 2). At night, the average contribution of pre-treatment SOM decomposition to total $R_{\mathrm{S}}$ was $20.0 \pm 2.2 \%$, ranging from $14.9 \pm 6.3 \%$ in June to $24.8 \pm 5.3 \%$ in September (Table 2).

We also tested whether the increases seen in $R_{\mathrm{S}}$ during the summer were due to $R_{\mathrm{R}}$ or $R_{\mathrm{H}}$ (i.e. $R_{\mathrm{SOM}}+R_{\mathrm{L}}$ ). Both daytime and nighttime $R_{\mathrm{S}}$ rates increased during the sum$\operatorname{mer}(t=4.50 ; p<0.0001)$ compared to late spring and early fall (see the Supplement for details). Daytime and nighttime rates of $R_{\mathrm{R}}$ also increased significantly during the July and August periods compared to June and September $(t=$ $3.11 ; p=0.0022)$, whereas $R_{\mathrm{H}}$ did not statistically increased 


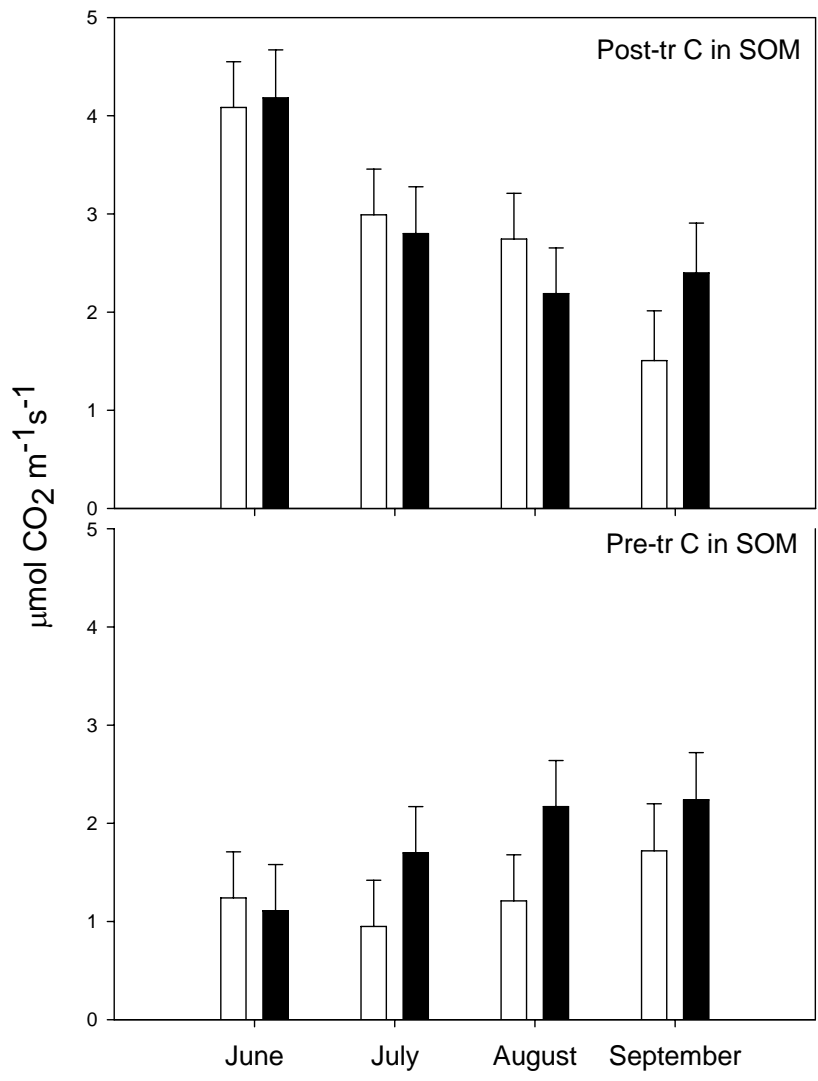

Fig. 4. The contribution of post- and pre-treatment soil organic carbon to daytime and nighttime soil respiration at FACTS-1 during the growing season of 2004. Values are means $(n=3) \pm$ standard error.

respiration rates during this period ( $t=0.74, p=0.45)$. Therefore, seasonal variation in $R_{\mathrm{R}}$ contributed to variations in $R_{\mathrm{S}}$.

\subsection{Temperature and moisture relationships with components of $R_{S}$}

There were no significant differences in daytime and nighttime soil temperature or moisture for the measurement periods in this study (t-test, $p>0.05$ ). Seasonal patterns of total $\mathrm{CO}_{2}$ efflux were influenced by temperature $\left(R^{2}=0.32\right)$ and moisture $\left(R^{2}=0.28\right)$, particularly at night where combined soil temperature and moisture could explained $66 \%$ of seasonal nighttime variations in $R_{\mathrm{S}}(p<0.05)$. However, at diurnal time scales these interactions were not significant, mostly due to lack of soil temperature changes between day and night (except for June 2004 where night respiration was slightly lower than daytime respiration).

In 2004, the components of soil respiration also showed little sensitivity to diurnal changes in soil temperature, as some components of $R_{\mathrm{S}}$ increased, decreased or remained unchanged diurnally. Again there was little diurnal change in temperature between day and night, illustrating biotic interactions in diel variation of some $R_{\mathrm{S}}$ components. Moisture variations were relatively modest both diurnally and seasonally and volumetric water content remained above 0.2 (Table 3), and therefore regressions were not significant with the flux variables.

At seasonal time scales, both daytime $\left(R^{2}=0.78\right)$ and nighttime $\left(R^{2}=0.40\right) R_{\mathrm{R}}$ were correlated with soil temperature (see the Supplement). Flux variations in the other $R_{\mathrm{S}}$ components were insensitive to temperature and moisture. Litter respiration maybe more sensitive to air temperature than soil temperature. Air canopy temperature had about $6^{\circ} \mathrm{C}$ variation between day and night during the summer months. Litter respiration was not significantly correlated to air temperature at diurnal time scales as $R_{\mathrm{L}}$ did not exhibit a diurnal pattern. Seasonally, daytime $R_{\mathrm{L}}$ was slightly correlated with lower canopy air temperature $\left(R^{2}=0.26\right)$ whereas nighttime $R_{\mathrm{L}}$ was poorly correlated with air temperature $\left(R^{2}=0.15\right)$.

\subsection{Sensitivity analyses for isotope and error accumulation}

Error accumulation was initially minimized by applying the mixing models at the individual collar level (12 per ring). With this approach the within ring standard errors were analyzed and they were between $2.7 \%$ and $6.9 \%$ of the value of the mean depending on the $R_{\mathrm{S}}$ component, time of measurement and ring. Therefore the within ring variation in rates was similar or smaller than variation seen across rings $(n=3)$. Also the compound estimates of $R_{\mathrm{S}}$ using the isotope collar method were within $5 \%$ of $R_{\mathrm{S}}$ measurements made by other methods (e.g. Bernhardt et al., 2006; Taneva et al., 2006).

Errors can be introduced in the calculation of pre-and posttreatment $\mathrm{C}$ if isotopic variations at ambient rings if changes in the isotopic composition of $R_{\mathrm{S}}$ are caused by changes in the relative contribution between roots and heterotrophs. This potential error was probably small because there were small variations in the isotopic composition of root- and SOM- respired $\mathrm{CO}_{2}$ over time (Table 1). An unlikely more than a $60 \%$ shift in the relative contribution of $R_{\mathrm{R}}$ and $R_{\mathrm{H}}$ is needed to change the isotopic composition of soil-respired $\mathrm{CO}_{2}$ by $1 \%$ o. A sensitivity analysis considering this unlikely large abrupt change in the $R_{\mathrm{R}}$ and $R_{\mathrm{H}}$ contributions to $R_{\mathrm{S}}$ at ambient shows that it will induce a less than $6 \%$ error in the relative separation of pre- and post-treatment $\mathrm{C}$ at the elevated plots.

In addition, errors can be introduced with rapid variation in the isotopic composition of respired- $\mathrm{CO}_{2}$ from roots, rootfree soil or forest floor litter. It has been documented that the isotopic composition of respired $\mathrm{CO}_{2}$ can shift relatively rapid with respect to the isotopic composition of metabolized substrate, gas diffusion, or other factors (see Vargas et al., 2011). In this experiment, the isotopic composition of 
Table 3. Soil temperature at $10 \mathrm{~cm}\left({ }^{\circ} \mathrm{C}\right)$, volumetric soil water content at $10 \mathrm{~cm}$ and lower canopy air temperature $\left({ }^{\circ} \mathrm{C}\right)$ in the treatment plots at FACTS-1. Reported values are means and standard error $(n=3)$ of the days experiments were made.

\begin{tabular}{|c|c|c|c|c|c|c|}
\hline \multirow[b]{2}{*}{ Month } & \multicolumn{2}{|c|}{ Soil Temperature $\left({ }^{\circ} \mathrm{C}\right)$} & \multicolumn{2}{|c|}{ Soil Moisture (\% vol) } & \multicolumn{2}{|c|}{ Lower Canopy Air Temperature $\left({ }^{\circ} \mathrm{C}\right)$} \\
\hline & Day & Night & Day & Night & Day & Night \\
\hline June & $20.2 \pm 0.3$ & $20.3 \pm 0.3$ & $0.21 \pm 0.01$ & $0.21 \pm 0.01$ & $25.0 \pm 0.4$ & $18.1 \pm 0.6$ \\
\hline July & $21.3 \pm 0.2$ & $21.4 \pm 0.2$ & $0.20 \pm 0.02$ & $0.20 \pm 0.02$ & $25.9 \pm 0.4$ & $19.5 \pm 0.2$ \\
\hline August & $21.2 \pm 0.1$ & $21.3 \pm 0.1$ & $0.28 \pm 0.03$ & $0.27 \pm 0.03$ & $24.8 \pm 0.2$ & $17.8 \pm 0.4$ \\
\hline September & $19.1 \pm 0.6$ & $19.2 \pm 0.4$ & $0.29 \pm 0.00$ & $0.29 \pm 0.00$ & $21.5 \pm 0.2$ & $17.3 \pm 0.4$ \\
\hline
\end{tabular}

respired- $\mathrm{CO}_{2}$ from each belowground source was measured rather than using the isotopic composition of a given bulk tissue or pool (Table 2). The use of measured $\delta^{13} \mathrm{C}$ of respired $\mathrm{CO}_{2}$ shall integrate the isotopic variations caused by intrinsic or environmental conditions for each pool and every time the $R_{\mathrm{S}}$ component partitioning was made (e.g. Hymus et al., 2005; Moore et al., 2008). Extrapolation of the measured $\delta^{13} \mathrm{C}$ of respired $\mathrm{CO}_{2}$ values over time (less than $24 \mathrm{~h}$ in this study) may induce errors if rapid isotopic variation of respired- $\mathrm{CO}_{2}$ occurs. To account for this potential variation, we performed a sensitivity analysis for each month and time of day for which the component partitioning of Rs was done. We calculated the effect of an error of $1.5 \%$ shift in the measured versus real isotopic composition of respired $\mathrm{CO}_{2}$ for any given endmember at any given time and analyzed the resulting component partitioning of $R_{\mathrm{S}}$. The sensitivity analyses revealed that for every $1 \%$ change in the isotopic composition of respired- $\mathrm{CO}_{2}$ form either roots, root-free soil or litter, the $R_{\mathrm{R}}$ component of $R_{\mathrm{S}}$ varied up to $15 \%$, whereas the variation in the $R_{\mathrm{SOM}}$ or $R_{\mathrm{L}}$ contribution to $R_{\mathrm{S}}$ changed by less than $6 \%$ on average.

\section{Discussion}

In this study, we document that variations in individual components of $R_{\mathrm{S}}$ do not always lead to measurable variations in overall $R_{\mathrm{S}}$ efflux rates. Conversely, changes in $R_{\mathrm{S}}$ may not be always attributed to a one single component. We also report that diel differences in rates of $R_{\mathrm{S}}$ components are not easily explained by passive temperature and moisture controls, and that biotic controls on $R_{\mathrm{H}}$ are also important in determining rates of SOM oxidation. This is particularly evidenced by the diurnal pattern of oxidation of old C $\left(R_{\text {pre-tr }}\right)$. While this is not the first study to separate $R_{\mathrm{S}}$ into more than two components (Sulzman et al., 2005; Cisneros-Dozal et al., 2006; Subke et al., 2011; Vargas et al., 2011), to our knowledge, this is among the first reports of the diel and seasonal changes in the contribution of four $R_{\mathrm{S}}$ components to growing season efflux rates under field conditions. Our results suggest that fine controls on individual components contributing to soil $\mathrm{CO}_{2}$ efflux could result in different responses to similar biotic and abiotic variables. Understanding the sources of soil $\mathrm{CO}_{2}$ efflux and its dependent biotic and abiotic controls are important in elucidating the environmental effects on $R_{\mathrm{S}}$ rates at different time scales.

By taking advantage of the ecosystem ${ }^{13} \mathrm{C}$ tracer we were able to examine if and how the temporal dynamics of $R_{\mathrm{S}}$ components translate into temporal variability of total $R_{\mathrm{S}}$. Due to the lack of a ${ }^{13} \mathrm{C}$ tracer in the control plots at the Duke Forest FACE site, we were only able to study $R_{\mathrm{S}}$ components under ecosystem exposure to elevated $\left[\mathrm{CO}_{2}\right]$ and a comparison of the contributions of different $R_{\mathrm{S}}$ components under ambient and elevated $\mathrm{CO}_{2}$ conditions was not possible. Therefore, the interpretation of results is within the constraints of the sensitivity analyses of using a single isotope, and influenced by the effects of elevated $\mathrm{CO}_{2}$ in below ground forest dynamics.

\subsection{Soil respiration and its autotrophic and heterotrophic components}

Several studies have reported increased $R_{\mathrm{S}}$ rates under elevated $\left[\mathrm{CO}_{2}\right]$ (King et al., 2004; Bernhardt et al., 2006; Taneva et al., 2006) and our results are in agreement with these reports for the growing season of 2004 but not for 2003 (Fig. 1). There were little cumulative climatic differences between the growing seasons of 2003 and 2004, but the growing season of 2002 was slightly dryer than normal. In 2002, both net primary productivity and belowground $\mathrm{C}$ allocation of the forest exposed to high $\mathrm{CO}_{2}$ reached the lowest values since 1996 (Finzi et al., 2006), which may have caused a legacy effect on belowground processes during the following year (decreased storage $\mathrm{C}$, lower root production, etc). During both growing seasons, $R_{\mathrm{S}}$ showed a strong seasonal pattern but not a diurnal pattern (Fig. 1). The presence or absence of diurnal variability of total $R_{\mathrm{S}}$ rate could not be attributed to variability in the rate of any single $R_{\mathrm{S}}$ component (Table 3 ), although the seasonal variability seemed to be partly driven by changes in $R_{\mathrm{R}}$.

The contribution of $R_{\mathrm{R}}$ to total $R_{\mathrm{S}}$ ranged from 14 to $37 \%$ during the day in this forest. This range is on the lower end of the annual range of 20-84\% reported for temperate coniferous forests (reviewed by Subke et al., 2006) and lower than previous annual estimates at the site using midday rates of $R_{\mathrm{S}}$ (Andrews et al., 1999; Hamilton et al., 2002). The proportion 
of $R_{\mathrm{R}}$ in $R_{\mathrm{S}}$ from this study is consistent with the relatively low levels of root productivity and turnover as compared to other temperate forests (Matamala and Schlesinger, 2000; Matamala et al., 2003). Subke et al. (2006) reported a relative increase in the contribution of $R_{\mathrm{R}}$ to $R_{\mathrm{S}}$ as the rate of $R_{\mathrm{S}}$ increases, as is the case of this study (Table 3), suggesting that $R_{\mathrm{R}}$ may influence $R_{\mathrm{S}}$ during the growing season (see the Supplement, Vargas et al., 2011).

Although we found $R_{\mathrm{R}}$ to be temperature sensitive over seasonal time scales, $R_{\mathrm{S}}$ was poorly correlated to changes in soil temperature or moisture at both diurnal and seasonal time scales. There is a growing body of evidence that $R_{\mathrm{S}}$ shows a diurnal hysteretic response in many ecosystems (Vargas et al., 2011), suggesting biotic interactions may mask abiotic controls on $R_{\mathrm{S}}$. Hysteresis in $R_{\mathrm{S}}$ has now been reported in a variety of ecosystems (Gaumont-Guay et al., 2006; Barron-Gafford et al., 2010; Philips et al., 2011), and may be caused by changes in photosynthesis, use of $\mathrm{C}$ and $\mathrm{N}$ reserves, hydraulic lift, or phenology (Högberg et al., 2001; Barron-Gafford et al., 2010; Vargas et al., 2011). These factors could affect rates of $R_{\mathrm{R}}$ which will translate into rates of $R_{\mathrm{S}}$ as a function of the relative contribution of $R_{\mathrm{R}}$ to $R_{\mathrm{S}}$. It is less known how biotic interactions affect diurnal and seasonal patterns of $R_{\mathrm{H}}$.

Heterotrophic respiration was the dominant component of growing season $R_{\mathrm{S}}$ in this forest, constituting 63 to $86 \%$ of daytime $R_{\mathrm{S}}$ rates (Table 2), within the reported range of 16$80 \%$ for the contribution of $R_{\mathrm{H}}$ to $R_{\mathrm{S}}$ in temperate coniferous forests (Subke et al., 2006). Heterotrophic respiration was also fueled by a substantial contribution of post-treatment $\mathrm{C}$ (Table 2, Fig. 2). Although it is widely recognized that $R_{\mathrm{H}}$ can result from a number of soil C pools, $R_{\mathrm{H}}$ is usually treated as a single $R_{\mathrm{S}}$ component. In this study, we further partitioned $R_{\mathrm{H}}$ into litter decomposition $\left(R_{\mathrm{L}}\right)$ and SOM decomposition $\left(R_{\mathrm{SOM}}\right.$, Table 2$)$. The proportion of $R_{\mathrm{L}}$ in $R_{\mathrm{S}}$ ranged from 0 to $51 \%$ of total $R_{\mathrm{S}}$, which is consistent with a range of 1 to $42 \%$ of $R_{\mathrm{S}}$ shown during the growing season of a temperate deciduous forest (Cisneroz-Dozal et al., 2006). This variability in the proportion of $R_{\mathrm{L}}$ in $R_{\mathrm{S}}$ may be due to changes in forest floor moisture content (Hanson et al., 2003; Goulden et al., 2004; Lee et al., 2004). However we found only a modest relationship between $R_{\mathrm{L}}$ rates and soil moisture and air temperature, suggesting other possible controls on $R_{\mathrm{L}}$ in this forest (see Malcom et al., 2009). One such control on $R_{\mathrm{L}}$ could be litter mass (unfortunately forest floor mass variation was not measured). Litter decomposition rates are expressed on per ground area basis and changes in litter mass can affect the per ground area litter flux. Although $R_{\mathrm{L}}$ on a per mass basis can respond to moisture changes as reported earlier (e.g. Hanson et al., 2003) changes in litter mass over the course of the growing season can result in different seasonal rates of $R_{\mathrm{L}}$, masking the temperature and moisture sensitivities of litter decomposition in this forest.

\subsection{Temporal variability in total $R_{\mathrm{S}}$ and $\boldsymbol{R}_{\mathrm{S}}$ components}

While greater rates of $R_{\mathrm{R}}$ in July and August were correlated with increased $R_{\mathrm{S}}$, the contribution of $R_{\mathrm{H}}\left(R_{\mathrm{SOM}}\right.$ and $\left.R_{\mathrm{L}}\right)$ to $R_{\mathrm{S}}$ was not constant during the growing season (Table 2), indicating that seasonal variability in $R_{\mathrm{R}}$ alone cannot explain the seasonal variability in $R_{\mathrm{S}}$. Notably, when $R_{\mathrm{S}}$ rates were at their highest, the rates of both $R_{\mathrm{R}}$ and $R_{\mathrm{SOM}}$ increased. These results indicate that increases in overall $R_{\mathrm{S}}$ rates are not always solely driven by root and rhizosphere activity, as seen in other studies (e.g. Högberg et al., 2001). Different soil C pools may interact to produce observed rates of $R_{\mathrm{S}}$ and measurements of soil $\mathrm{CO}_{2}$ efflux alone cannot account for the variability of and interactions between $R_{\mathrm{S}}$ components (Trueman and Gonzalez-Meler, 2005).

Although daytime $R_{\mathrm{S}}$ did not differ significantly from nighttime rates, there were significant diel changes in individual $R_{\mathrm{S}}$ components (Figs. 1 and 3 ). All three components of $R_{\mathrm{S}}\left(R_{\mathrm{R}}, R_{\mathrm{SOM}}\right.$, and $\left.R_{\mathrm{L}}\right)$ had significantly different rates between day and night, although the magnitude and direction of the rate difference varied throughout the growing season. For instance, the contribution of $R_{\mathrm{R}}$ to total $R_{\mathrm{S}}$ was greater at night later in the season than during the day (Table 2). The observed diel differences in $R_{\mathrm{R}}$ are likely the result of the diurnal variability in the allocation of photosynthetic $\mathrm{C}$ to roots (Trueman and Gonzalez-Meler, 2005; Tang et al., 2005) and not necessarily to just changes in soil temperature and moisture; changes in daytime and nighttime values of soil temperature and moisture were small to detect their effects on diurnal variations in rates (Table 3). Because the diel differences in $R_{\mathrm{R}}$ were not always significant in this study, the time lag between photosynthesis and $R_{\mathrm{R}}$ may not be constant during the growing season of this forest (Tang et al., 2005; Vargas et al., 2011; but see Stoy et al., 2007).

Indirect evidence has shown that $R_{\mathrm{R}}$ may be a possible driver of $R_{\mathrm{S}}$ variability (Högberg et al., 2001; BondLamberty et al., 2004; Trueman and Gonzalez-Meler, 2005; Subke et al., 2006) including this study site (Palmroth et al., 2006). In this study, variability in $R_{\mathrm{R}}$ alone was insufficient in explaining the seasonal and diel variability of $R_{\mathrm{S}}$ because temporal changes in other $R_{\mathrm{S}}$ components could compensate for changes in $R_{\mathrm{R}}$. The average relative contribution of $R_{\mathrm{SOM}}$ to $R_{\mathrm{S}}$ was greater at night than during the day (Table 2). Since total rate of $R_{\mathrm{S}}$ did not differ between day and night, nighttime decreases in $R_{\mathrm{R}}$, perhaps due to the absence of photosynthesis, were compensated for by increases in nighttime rates of $R_{\mathrm{SOM}}$, increasing its proportion in $R_{\mathrm{S}}$. However, lower $R_{\mathrm{R}}$ did not always translate to higher $R_{\mathrm{SOM}}$ during the nighttime (Fig. 3 and Table 2). Whether these variations were independent or the result of more complex interactions needs further study, but points to complex heterogeneity in pools contributing to $R_{\mathrm{H}}\left(R_{\mathrm{SOM}}+R_{\mathrm{L}}\right)$. As indicated above, the rate of $R_{\mathrm{L}}$ was the smallest of the components that contribute to the rate of total $R_{\mathrm{S}}$ (Fig. 3) and therefore unlikely to be the major player in causing $R_{\mathrm{S}}$ variability. 
In contrast, $R_{\mathrm{SOM}}$ was the largest component contributing to $R_{\mathrm{S}}$ and it is also the more heterogeneous soil pool. Soil organic matter is often partitioned into static size and/or chemical fractions that often correspond with $\mathrm{C}$ average age (e.g. O'Brien et al., 2011). At the Duke FACE study site, C fixed after fumigation started has been incorporated in almost all soil fractions (Matamala et al., 2003; Lichter et al., 2008), but the measured mean residence time of these soil $\mathrm{C}$ pools contrast with the shorter time-scales at which pre- and posttreatment $\mathrm{C}$ contributed to soil $\mathrm{CO}_{2}$ and soil respired $\mathrm{CO}_{2}$ from these pools (Taneva et al., 2006), suggesting heterogeneous labiality within a soil $\mathrm{C}$ pool in this forest. In 2004, pre-treatment $\mathrm{C}$ in $R_{\mathrm{S}}$ (fixed by the ecosystem prior to 1996) mostly originated from heterotrophic sources and represents a $\mathrm{C}$ pool with close to decadal and longer mean residence times. Pre-treatment C respiration $\left(R_{\text {pre-tr }}\right)$ may contribute to up to $20 \%$ of total $R_{\mathrm{L}}$ but because $R_{\mathrm{L}}$ represented less than $20 \%$ of seasonal $R_{\mathrm{S}}$ (see above, Tables 1 and 2 ), $95 \%$ of pretreatment $\mathrm{C}$ in $R_{\mathrm{S}}$ should originate from $R_{\mathrm{SOM}}$. Therefore, $R_{\text {SOM }}$ can be further partitioned into pre- and post-treatment $\mathrm{C}$ respiration.

Within $R_{\mathrm{SOM}}$, the decomposition of $\mathrm{C}$ older than $8 \mathrm{yr}$ $\left(R_{\text {pre-tr }}\right)$ showed more pronounced and consistent diel differences than any other $R_{\mathrm{S}}$ component, with nighttime rates on average $29 \%$ higher than its daytime rates. In contrast, the decomposition of post-treatment C ( $\left.R_{\text {post-tr }}\right)$ did not differ between day and night, suggesting that the variability in $R_{\mathrm{SOM}}$ appear to be due to changes in the decomposition of older $\mathrm{C}$ pools, rather than the decomposition of recently added SOM. The decomposition of pre-treatment older $\mathrm{C}$ increased over the course of the growing season. The diel sensitivity of soil $\mathrm{C}$ pools older than 8 years suggests that all SOM pools can rapidly respond to ecosystem exposure to environmental change through their biotic and abiotic controls (as suggested by Vargas et al., 2011).

The decomposition of older soil $\mathrm{C}$ pools constituted a substantial fraction of total $R_{\mathrm{S}}$ during the growing season of this forest (Table 2) and appeared to be as variable as $R_{R}$. Our results indicate that plant activity may exert a direct and/or indirect control over $R_{\mathrm{S}}$ through cascading effects on other $R_{\mathrm{S}}$ components beyond $R_{\mathrm{R}}$. Plant activity has been previously linked to greater rates of SOM decomposition (Kuzyakov and Cheng, 2001; Kuzyakov, 2002; Subke et al., 2004; Trueman and Gonzalez-Meler, 2005) and an increasing number of studies have indicated that $R_{\mathrm{S}}$ components are not independent of each other, but have interactive effects on $R_{\mathrm{S}}$ (Trueman and Gonzalez-Meler, 2005; Vargas et al., 2011). These studies indicate that predicted increases in above- and belowground NPP with elevated $\left[\mathrm{CO}_{2}\right]$ may not necessarily translate into greater soil $\mathrm{C}$ storage, as increases in plant activity may simultaneously increase the decomposition of recent and older C in forests (Hoosbeek et al., 2004; Subke et al., 2004; Sulzman et al., 2005; Trueman and Gonzalez-Meler, 2005). Despite the importance of potential priming of old SOM decomposition by enhanced plant activity with chang- ing environmental conditions, mechanisms of this priming remain poorly understood (Trueman and Gonzalez-Meler, 2005; Kuzyakov and Gravrichkova, 2010).

The presence of unpredictable diel patterns in the rates of $R_{\mathrm{S}}$ components, with no changes in soil temperature or moisture, suggests that primary and secondary responses of decomposers to changes in soil conditions exist (Trueman and Gonzalez-Meler, 2005; Vargas et al., 2011) including the physiological thermal acclimation of decomposers (Bradford et al., 2008). Therefore, extrapolation of daytime measurements of $R_{\mathrm{S}}$ to monthly or annual scales or application of growing season $Q_{10}$ values to annual $R_{\mathrm{S}}$ may introduce a bias in long-term ecosystem $\mathrm{C}$ budgets. In our study, decomposition of SOM, particularly pre-treatment SOM ( $\left.R_{\text {pre-tr }}\right)$, was the only $R_{\mathrm{S}}$ component that exhibited consistently higher contribution to $R_{\mathrm{S}}$ at night, which increased towards the end of the growing season, despite no significant differences in intrinsic decomposition kinetics between $\mathrm{C}_{\text {pre-tr }}$ and $\mathrm{C}_{\text {post-tr }}$ at FACTS-1 (Taneva and GonzalezMeler, 2008) or other studies (Trueman et al., 2009). These results suggest that the oxidation of older SOM may be affected by short-term environmental or biotic controls that may result from interactions between plant and decomposer activity. It is possible that root activity during the daytime interacts with decomposition of older SOM through competition for nutrients and water or through the availability of rhizodeposits (e.g. Kuzyakov and Cheng, 2001).

In summary, the results from these experiments show that the lack of diel changes in total $R_{\mathrm{S}}$ cannot be interpreted as a sign that source components within $R_{\mathrm{S}}$ do not vary. Conversely, because the diel changes in the four components of $R_{\mathrm{S}}$ we measured were not consistent, the seasonal variation seen in $R_{\mathrm{S}}$ for this forest cannot be attributed to proportional variation within these components. Although our results are constrained by the single isotope approach and by the elevated $\left[\mathrm{CO}_{2}\right]$ conditions, these results suggest that there are interactions between components of $R_{\mathrm{S}}$ at both diel and seasonal time scales. Although the nature of these interactions could not be elucidated here, they influence the temperatureand moisture-dependent functions of total $R_{\mathrm{S}}$, as soil organisms and roots are likely to actively modulate their activity rather than passively respond to biotic and abiotic factors. Understanding these interactions and how they may elicit the decomposition of old stored soil $\mathrm{C}$ in response to changing environmental conditions is paramount to elucidate the effects of $R_{\mathrm{S}}$ and its components on the atmospheric concentration of greenhouse gases.

\section{Supplementary material related to this article is available online at: http://www.biogeosciences.net/8/3077/2011/ bg-8-3077-2011-supplement.pdf.}


Acknowledgements. This research was funded by NSF to MAG-M and by a University of Illinois at Chicago Graduate Fellowship to L. T. We gratefully acknowledge the staff of Brookhaven National Laboratory and the Duke Forest for maintenance and operation of the FACTS-1 experiment. We thank A. Niederland, J. S. Pippen, and T. Sagimoto for help in the field and Leah Simoni, Sergey Oleynik, and Matt Lorz for assistance in the laboratory. We thank Jim Burns for his help with statistical analyses. Dave Moore, Rich J. Norby and A. Rocha provided constructive and insightful comments on earlier versions of this manuscript. The FACTS-1 experiment is supported by the Office of Science (BER), US Department of Energy.

Edited by: A. Knohl

\section{References}

Andrews, J. A., Harrison, K. G., Matamala, R., and Schlesinger, W. H.: Separation of root respiration from total soil respiration using Carbon-13 labeling during FACE, Soil Sci. Soc. Am. J., 63, 1429-1435, 1999.

Balesdent, J., and Mariotti, A.: Measurement of soil organic matter turnover using ${ }^{13} \mathrm{C}$ natural abundance Marcel Dekker, Inc., New York, NY, 1996.

Barron-Gafford, G. A., Scott, R. L., Jenerette, G. D., and Huxman, T. E.: The relative controls of temperature, soil moisture, and plant functional group on soil $\mathrm{CO}_{2}$ efflux at diel, seasonal, and annual scales, J. Geophys. Res.-Biogeo., 116, G01023, doi:10.1029/2010JG001442, 2010.

Bernhardt, E. S., Barber, J. J., Pippen, J. S., Taneva, L., Andrews, J. A., and Schlesinger, W. H.: Long-term effects of free air $\mathrm{CO}_{2}$ enrichment (FACE) on soil respiration, Biogeochemistry, 77, 91116, 2006.

Bond-Lamberty, B., Wang, C., and Gower, S. T.: A global relationship between the heterotrophic and autotrophic components of soil respiration?, Glob. Change Biol., 10, 1756-1766, 2004.

Bowling, D. R., McDowell, N. G., Bond, B. J., Law, B. E., and Ehleringer, J. R.: ${ }^{13} \mathrm{C}$ content of ecosystem respiration is linked to precipitation and vapor pressure deficit, Oecologia, 131, 113124, 2002.

Bowling, D. R., Pataki, D. E., and Randerson, J. T.: Carbon isotopes in terrestrial ecosystem pools and $\mathrm{CO}_{2}$ fluxes, New Phytol., 178, 24-40, 2008.

Bradford, M. A., Davies, C. A., Frey, S. D., Maddox, T. R., Melillo, J. M., Mohan, J. E., Reynolds, J. F., Treseder, K. K., and Wallenstein, M. D.: Thermal adaptation of soil microbial respiration to elevated temperature, Ecol. Lett., 11, 1316-1327, 2008.

Carbone, M. S., Czimczik, C. I., McDuffee, K. E., and Trumbore, S. E.: Allocation and residence time of photosynthetic products in a boreal forest using a low-level C-14 pulse-chase labeling technique, Glob. Change Biol., 14, 466-477, 2007.

Cisneros-Dozal, L. M., Trumbore, S. E., and Hanson, P. J.: Partitioning sources of soil-respired $\mathrm{CO}_{2}$ and their seasonal variation using a unique radiocarbon tracer, Glob. Change Biol., 12, 194204, 2006.

Davidson, E. A. and Janssens, I. A.: Temperature sensitivity of soil carbon decomposition and feedbacks to climate change, Nature, 440, 165-173, 2006.
Davidson, E. A., Richardson, A. D., Savage, K. E., and Hollinger, D. Y.: A distinct seasonal pattern of the ratio of soil respiration to total ecosystem respiration in a spruce-dominated forest, Glob. Change Biol., 12, 230-239, 2006.

DeLucia, E. H., Drake, J. E., Thomas, R. B., and Gonzalez-Meler, M. A.: Forest Carbon Use Efficiency: Is Respiration a Constant Fraction of Gross Primary Production?, Glob. Change Biol., 13, 1157-1167, 2007.

Ekblad, A. and Hogberg, P.: Natural abundance of ${ }^{13} \mathrm{C}$ in $\mathrm{CO}_{2}$ respired from forest soils reveals speed of link between tree photosynthesis and root respiration, Oecologia, 127, 305-308, 2001.

Ellsworth, D. S.: $\mathrm{CO}_{2}$ enrichment in a maturing pine forest: are $\mathrm{CO}_{2}$ exchange and water status in the canopy affected?, Plant Cell Environ., 22, 461-472, 1999.

Finzi, A. C., Moore, D. J., DeLucia, E. H., Kim, H.-S., Jackson, R. B., Lichter, J., McCarthy, H., Oren, R., Pippen, J. S., and Schlesinger, W. H.: Progressive nitrogen limitation of ecosystem processes under elevated $\mathrm{CO}_{2}$ in a warm-temperate forest, Ecology, 87, 15-25, 2006.

Gaumont-Guay, D., Black, T. A., Griffis, T. J., Barr, A. G., Jassal, R. S., and Nesic, Z.: Interpreting the dependence of soil respiration on soil temperature and water content in a boreal aspen stand, Agr. Forest Meteorol., 140, 220-235, 2006.

Gonzalez-Meler, M. A. and Taneva, L.: Integrated Effects of Atmospheric $\mathrm{CO}_{2}$ Concentration on Plant and Ecosystem Respiration, edited by: Plant Respiration, in: Lambers, H. and Ribas-Carbo, Kluwer-Academic Publishers, Dordrecht, 211-259, 2005.

Gonzalez-Meler, M. A., Taneva, L., and Trueman, R. J.: Plant Respiration and Elevated Atmospheric $\mathrm{CO}_{2}$ Concentration: Cellular Responses and Global Significance, Ann. Bot., 94, 647-656, 2004.

Goulden, M. L., Miller, S. D., da Rocha, H. R., Menton, M. C., de Freitas, H. C., de Silva Figueira, A. M., and de Sousa, C. A. D.: Diel and seasonal patterns of tropical forest $\mathrm{CO}_{2}$ exchange, Ecol. Appl., 14, S42-S54, 2004.

Hamilton, J. G., DeLucia, E. H., George, K., Naidu, S. L., Finzi, A. C., and Schlesinger, W. H.: Forest carbon balance under elevated $\mathrm{CO}_{2}$, Oecologia, 131, 250-260, 2002.

Hanson, P. J., Edwards, N. T., Garten, C. T., and Andrews, J. A.: Separating root and soil microbial contributions to soil respiration: A review of methods and observations, Biogeochemistry, 48, 115-146, 2000.

Hanson, P. J., O’Neill, E. G., Chambers, M. L. S., Riggs, J. S., Joslin, J. D., and Wolfe, M. H.: Soil respiration and litter decomposition, Springer, New York, NY, 2003.

Heath, J., Ayres, E., Possell, M., Bardgett, R. D., Black, H. I. J., Grant, H., Ineson, P., and Kerstiens, G.: Rising Atmospheric $\mathrm{CO}_{2}$ Reduces Sequestration of Root-Derived Soil Carbon, Science, 309, 1711-1713, 2005.

Hedeker, D., Gibbons, R. D., and Flay, B. R.: Random-effects regression models for clustered data with an example from smoking prevention research, J. Consult. Clin. Psych., 62, 757-765, 1994.

Hendrey, G. R., Ellsworth, D. S., Lewin, K. F., and Nagy, J.: A freeair enrichment system for exposing tall forest vegetation to elevated atmospheric $\mathrm{CO}_{2}$, Glob. Change Biol., 5, 293-309, 1999.

Högberg, P., Nordgren, A., Buchmann, N., Taylor, A. F.S ., Ekblad, A., Högberg, M. N., Nyberg, G., Ottosson-Löfvenius, M., and Read, D. J.: Large-scale forest girdling shows that current 
photosynthesis drives soil respiration, Nature, 411, 789-792, 2001.

Hoosbeek, M. R., Lukac, M., van Dam, D., Godbold, D. L., Velthorst, E. J., Biondi, F. A., Peressotti, A., Cotrufo, M. F., De Angelis, P., and Scarascia-Mugnozza, G.: More new carbon in the mineral soil of a poplar plantation under Free Air Carbon Enrichment (POPFACE): Cause of increased priming effect?, Global Biogeochem. Cy., 18, GB1040, doi:10.1029/2003GB002127, 2004.

Hymus, G. J., Maseyk, K., Valentini, R., and Yakir, D.: Large daily variation in ${ }^{13} \mathrm{C}$-enrichment of leaf-respired $\mathrm{CO}_{2}$ in two Quercus forest canopies, New Phytol., 167, 377-384, 2005.

Katul, G. G., Manzoni, S., Palmroth, S., and Oren, R.: A stomatal optimization theory to describe the effects of atmospheric $\mathrm{CO}_{2}$ on leaf photosynthesis and transpiration., Ann. Bot., 105, 431442, 2010.

Kayler, Z. E., Ganio, L., Hauck, M., Pypker, T. G., Sulzman, E. W., Mix, A. C., and Bond, B. J.: Bias and uncertainty of delta $\left(\mathrm{CO}_{2}\right)$ C-13 isotopic mixing models, Oecologia, 163, 227-234, 2010.

King, J. S., Hanson, P. J., Bernhardt, E. S., De Angelis, P., Norby, R. J., and Pregitzer, K. S.: A multiyear synthesis of soil respiration responses to elevated atmospheric $\mathrm{CO}_{2}$ from four forest FACE experiments, Glob. Change Biol., 10, 1027-1042, 2004.

Kuzyakov, Y.: Review: Factors affecting rhizosphere priming effect, J. Plant Nutr. Soil Sci., 165, 382-396, 2002.

Kuzyakov, Y. and Cheng, W.: Photosynthesis controls of rhizosphere respiration and organic matter decomposition, Soil Biol. Biochem., 33, 1915-1925, 2001.

Kuzyakov, Y. and Gavrichkova, O.: REVIEW: Time lag between photosynthesis and carbon dioxide efflux from soil: a review of mechanisms and controls, Glob. Change Biol., 16, 3386-3406, 2010

Lee, X., Wu, H.-J., Sigler, J., Oishi, C., and Siccama, T.: Rapid and transient response of soil respiration to rain, Glob. Change Biol., 10, 1017-1026, 2004.

Lichter, J., Billings, S. A., Ziegler, S., Gaindh, D., Ryals, R., Finzi, A. C., Jackson, R. B., Stemmler, E. A., and Schlesinger, W. S.: Soil carbon sequestration in a pine forest after 9 years of atmospheric $\mathrm{CO}_{2}$ enrichment, Glob. Change Biol., 14, 1-13, doi:10.1111/j.1365-2486.2008.01701.x, 2008.

Liu, Q., Edwards, N. T., Post, W. M., Gu, L., Ledford, J., and Lenhart, S.: Temperature-independent diel variation in soil respiration observed from a temperate deciduous forest, Glob. Change Biol., 12, 2136-2145, 2006.

Lloyd, J. and Taylor, J. A.: On the temperature dependence of soil respiration, Funct. Ecol., 8, 315-323, 1994.

Luo, Y.: Terrestrial Carbon-Cycle Feedback to Climate Warming, Annu. Rev. Ecol. Evol. Syst., 38, 683-712, 2007.

Makiranta, P., Minkkinen, K., Hytonen, J., and Laine, J.: Factors causing temporal and spatial variation in heterotrophic and rhizospheric components of soil respiration in afforested organic soil croplands in Finland, Soil Biol. Biochem., 40, 1592-1600, 2008.

Malcom, G. M., Lopez-Gutierrez, J. C., and Koide, R. T.: Little evidence for respiratory acclimation by microbial communities to short-term shifts in temperature in red pine (Pinus resinosa) litter, Glob. Change Biol., 15, 2485-2492, 2009.

Matamala, R. and Schlesinger, W. H.: Effects of elevated atmospheric $\mathrm{CO}_{2}$ on fine root production and activity in an intact temperate forest ecosystem, Glob. Change Biol., 6, 967-979, 2000.
Matamala, R., Gonzalez-Meler, M. A., Jastrow, J. D., Norby, R., and Schlesinger, W. D.: Slow root $\mathrm{C}$ turnover in forests: implications for carbon sequestration, Science, 302, 1385-1387, 2003.

Melillo, J. M., Steudler, P. A., Aber, J. D., Newkirk, K., Lux, H., Bowles, F. P., Catricala, C., Magill, A., Ahrens, T., and Morrisseau, S.: Soil Warming and Carbon-Cycle Feedbacks to the Climate System, Science, 298, 2173-2176, 2002.

Mencuccini, M. and Hölttä, T.: The significance of phloem transport for the speed with which canopy photosynthesis and belowground respiration are linked, New Phytol., 185, 189-203, 2010.

Moore, D. J. P., Gonzalez-Meler, M. A., Taneva, L., Pippen, J. S., Kim, H.-S., and DeLucia, E. H.: The effect of $\mathrm{CO}_{2}$ enrichment on apparent stem respiration from Pinus taeda L. is confounded by high levels of soil $\mathrm{CO}_{2}$, Oecologia, 158, 1-10, 2008.

Norby, R. J., Hanson, P. J., O’Neill, E. G., Tschaplinski, T. J., Weltzin, J. F., Hansen, R. T., Cheng, W., Wullschleger, S. D., Gunderson, C. A., Edwards, N. T., and Johnson, D. W.: Net primary productivity of a $\mathrm{CO}_{2}$-enriched deciduous forest and the implications for carbon storage, Ecol. Appl., 12, 1261-1266, 2002.

O'Brien, S. L., Jastrow, J. D., McFarlane, K. J., Guilderson, T. P., and Gonzalez-Meler, M. A.: Stable mineral-associated soil organic matter pools revealed by combined physical and chemical fractionation, Biogeochemistry, in press, 2011.

Orchard, V. A. and Cook, F. J.: Relationship between soil respiration and soil moisture, Soil Biol. Biochem., 15, 447-453, 1983.

Palmroth, S., Oren, R., McCarthy, H. R., Johnsen, K. H., Finzi, A. C., Butnor, J. R., and Ryan, M. G.: Aboveground sink strength in forests controls the allocation of carbon below ground and its $\left[\mathrm{CO}_{2}\right]$-induced enhancement, P. Natl. Acad. Sci., 103, 19362 19367, 2006.

Pataki, D. E., Ehleringer, J. R., Flanagan, L. B., Yakir, D., Bowling, D. R., Still, C. J., Buchmann, N., Kaplan, J. O., and Berry, J. A.: The application and interpretation of Keeling Plots in terrestrial carbon cycle research, Global Biogeochem. Cy., 17, 1022, doi:10.1029/2001GB001850, 2003.

Phillips, C. L., Nickerson, N., Risk, D., and Bond, B. J.: Interpreting diel hysteresis of soil respiration and temperature, Glob. Change Biol., 17, 515-527, doi:10.1111/j.13652486.2010.02250.x, 2010.

Phillips, D. L. and Gregg, J. W.: Uncertainty in source partitioning using stable isotopes, Oecologia, 127, 171-179, 2001.

Raich, J. W., Potter, C. S., and Bhagawati, D.: Interannual variability in global soil respiration, 1980-94, Glob. Change Biol., 8, 800-812, 2002.

Reichstein, M., Rey, A., and Freibauer, A.: Modelling temporal and large-scale spatial variability of soil respiration from soil water availability, temperature and vegetation productivity indices, Global Biogeochem. Cy., 17, 11-15, 2003.

Schlesinger, W. H. and Lichter, J.: Limited carbon storage in soil and litter of experimental forest plots under increased atmopsheric $\mathrm{CO}_{2}$, Nature, 411, 466-469, 2001.

Still, C. J., Berry, J. A., Ribas-Carbo, M., and Helliker, B. R.: The contribution of $\mathrm{C} 3$ and $\mathrm{C} 4$ plants to the carbon cycle of a tallgrass prairie: An isotopic approach, Oecologia, 136, 347-359, 2003.

Stoy, P. C., Palmroth, S., Oishi, A. C., Siqueira, M. B. S., Juang, J., Novick, K. A., Ward, E. J., Katul, G. G., and Oren, R. A. M.: Are ecosystem carbon inputs and outputs coupled at short time scales? A case study from adjacent pine and hardwood forests 
using impulse-response analysis, Plant Cell Environ., 30, 700710, doi:10.1111/j.1365-3040.2007.01655.x, 2007.

Subke, J.-A., Hahn, V., Battipaglia, G., Linder, S., Buchmann, N., and Cotrufo, M. F.: Feedback interactions between needle litter decomposition and rhizosphere activity, Oecologia, 139, 551$559,2004$.

Subke, J.-A., Inglima, I., and Cotrufo, M. F.: Trends and methodological impacts in soil $\mathrm{CO}_{2}$ efflux partitioning: A metaanalytical review, Glob. Change Biol., 12, 1-23, 2006.

Subke, J.-A., Voke, N. R., Leronni, V., Garnett, M. H., and Ineson, P.: Dynamics and pathways of autotrophic and heterotrophic soil $\mathrm{CO}_{2}$ efflux revealed by forest girdling, J. Ecol., 99, 186-193, 2011.

Sulzman, E. W., Brant, J. B., Bowden, R. D., and Lajtha, K.: Contribution of aboveground litter, belowground litter, and rhizosphere respiration to total soil $\mathrm{CO}_{2}$ effux in an old growth coniferous forest, Biogeochemistry, 73, 231-256, 2005.

Taneva, L. and Gonzalez-Meler, M. A.: Decomposition Kinetics of Soil Carbon of Different Age From a Forest Exposed to 8 Years of Elevated Atmospheric $\mathrm{CO}_{2}$ Concentration, Soil Biol. Biochem., 40, 2670-2677, 2008.

Taneva, L., Pippen, J. S., Schlesinger, W. H., and Gonzalez-Meler, M. A.: The turnover of carbon pools contributing to soil $\mathrm{CO}_{2}$ and soil respiration in a temperate forest exposed to elevated $\mathrm{CO}_{2}$ concentration, Glob. Change Biol., 12, 983-994, 2006.
Tang, J., Baldocchi, D. D., and Xu, L.: Tree photosynthesis modulates soil respiration on a diurnal time scale, Glob. Change Biol., 11, 1298-1304, 2005.

Trueman, R. J. and Gonzalez-Meler, M. A.: Accelerated belowground $\mathrm{C}$ cycling in a managed agriforest ecosystem exposed to elevated carbon dioxide concentrations, Glob. Change Biol., 11, 1258-1271, 2005.

Trueman, R. J., Taneva, L., Gonzalez-Meler, M. A., Oechel, W. C., and BasiriRad, H.: Carbon losses in soils previously exposed to elevated atmospheric $\mathrm{CO}_{2}$ in a chaparral ecosystem: Potential implications for a sustained biospheric C sink, J. Geochem. Explor., 102, 142-148, 2009.

Vargas, R., Carbone, M. S., Reichstein, M., and Baldocchi, D. D.: Frontiers and challenges in soil respiration research: from measurements to model-data integration, Biogeochemistry, 102, 113, 2011.

Wei, W., Weile, C., and Shaopeng, W.: Forest soil respiration and its heterotrophic and autotrophic components: Global patterns and responses to temperature and precipitation, Soil Biol. Biochem., 42, 1236-1244, 2010. 